\title{
Contribution of understorey vegetation and soil processes to boreal forest isoprenoid exchange
}

\author{
Mari Mäki $^{1}$, Jussi Heinonsalo ${ }^{2}$, Heidi Hellén ${ }^{3}$, and Jaana Bäck ${ }^{1}$ \\ ${ }^{1}$ Department of Forest Sciences, P.O. Box 27, 00014 University of Helsinki, Helsinki, Finland \\ ${ }^{2}$ Department of Food and Environmental Sciences, P.O. Box 66, 00014 University of Helsinki, Helsinki, Finland \\ ${ }^{3}$ Finnish Meteorological Institute, P.O. Box 503, 00101 Helsinki, Finland \\ Correspondence to: Mari Mäki (mari.maki@helsinki.fi)
}

Received: 14 June 2016 - Discussion started: 2 September 2016

Revised: 24 January 2017 - Accepted: 26 January 2017 - Published: 8 March 2017

\begin{abstract}
Boreal forest floor emits biogenic volatile organic compounds (BVOCs) from the understorey vegetation and the heterogeneous soil matrix, where the interactions of soil organisms and soil chemistry are complex. Earlier studies have focused on determining the net exchange of VOCs from the forest floor. This study goes one step further, with the aim of separately determining whether the photosynthesized carbon allocation to soil affects the isoprenoid production by different soil organisms, i.e., decomposers, mycorrhizal fungi, and roots. In each treatment, photosynthesized carbon allocation through roots for decomposers and mycorrhizal fungi was controlled by either preventing root ingrowth $(50 \mu \mathrm{m}$ mesh size $)$ or the ingrowth of roots and fungi $(1 \mu \mathrm{m}$ mesh) into the soil volume, which is called the trenching approach. Isoprenoid fluxes were measured using dynamic (steady-state flow-through) chambers from the different treatments. This study aimed to analyze how important the understorey vegetation is as a VOC sink. Finally, a statistical model was constructed based on prevailing temperature, seasonality, trenching treatments, understory vegetation cover, above canopy photosynthetically active radiation (PAR), soil water content, and soil temperature to estimate isoprenoid fluxes. The final model included parameters with a statistically significant effect on the isoprenoid fluxes. The results show that the boreal forest floor emits monoterpenes, sesquiterpenes, and isoprene. Monoterpenes were the most common group of emitted isoprenoids, and the average flux from the non-trenched forest floor was $23 \mu \mathrm{g} \mathrm{m}^{-2} \mathrm{~h}^{-1}$. The results also show that different biological factors, including litterfall, carbon availability, biological activity in the soil, and physico-chemical processes, such as volatilization and
\end{abstract}

absorption to the surfaces, are important at various times of the year. This study also discovered that understorey vegetation is a strong sink of monoterpenes. The statistical model, based on prevailing temperature, seasonality, vegetation effect, and the interaction of these parameters, explained $43 \%$ of the monoterpene fluxes, and $34-46 \%$ of individual $\alpha$ pinene, camphene, $\beta$-pinene, and $\Delta^{3}$-carene fluxes.

\section{Introduction}

Vegetation in coniferous forests is a primary and wellquantified source of biogenic volatile organic compounds (BVOCs) on the shoot level (Rinne et al., 2000; Hakola et al., 2003; Kim et al., 2005; Bäck et al., 2012; Aalto et al., 2014). The boreal forest floor, including tree roots, understorey vegetation (grasses, shrubs, mosses, lichens, and other vegetation), and the organic soil layer (different stages of decomposing litter, a variety of decomposing and other microorganisms) emits isoprenoids. According to earlier studies, the boreal forest floor emits monoterpenes (Aaltonen et al., 2011, $5 \mu \mathrm{g} \mathrm{m}^{-2} \mathrm{~h}^{-1}$, and Hellén et al., 2006, 0-373 $\mu \mathrm{g} \mathrm{m}^{-2} \mathrm{~h}^{-1}$ ), isoprenes (Aaltonen et al., 2011, $0.050 \mu \mathrm{g} \mathrm{m}^{-2} \mathrm{~h}^{-1}$, and Hellén et al., 2006, 0-1.9), and sesquiterpenes (Aaltonen et al., 2011, $0.045 \mu \mathrm{g} \mathrm{m}^{-2} \mathrm{~h}^{-1}$ and Hellén et al., 2006, 0-0.8 $\mu \mathrm{g} \mathrm{m}^{-2} \mathrm{~h}^{-1}$ : $\beta$-caryophyllene). Soil and understorey monoterpene emissions in pine forest are rather variable in time, but at their maximum they can make up to $10-15 \%$ of the ecosystem scale emissions (Aaltonen et al., 2013). Isoprenoids are a lipophilic group of volatile organic compounds (VOCs) emitted in trace amounts. Iso- 
prenoids are poorly water-soluble and highly reactive in the atmosphere. Isoprenoids are a very diverse group of chemical species (Guenther, 2013). Daytime lifetimes of isoprene, monoterpenes, and sesquiterpenes in the ambient air vary from hours to minutes (Rinne et al., 2007; Bouvier-Brown et al., 2009; Guenther, 2013; Peräkylä et al., 2014).

Forest floor was discovered to be a significant monoterpene source during spring and fall, when photosynthesis is low (Hellén et al., 2006; Aaltonen et al., 2011, 2013). On the forest floor, understorey vegetation emits monoterpenes (Aaltonen et al., 2011; Faubert et al., 2012) and photosynthesized energy regulates isoprene syntheses (Ghirardo et al., 2011). Large biomass or coverage of understorey vegetation can also decrease the total measured VOC flux from soil because transpiration can induce the formation of water film on the leaf and chamber inner surfaces, which can enhance isoprenoid absorption (Aaltonen et al., 2013). Trees allocate $40-73 \%$ of the photosynthesized carbon for root metabolism, growth, and root-associated microbes (Grayston et al., 1997), and the largest portion of photosynthesized carbon is consumed in the root-induced respiration of microbes. The belowground carbon allocation of labeled $\mathrm{C}^{13}$ from canopy photosynthesis can be 500\% higher in August than June (Högberg et al., 2010). Photosynthesized carbon allocated belowground was shown to contribute $54 \%$ of soil respiration (Högberg et al., 2001), but $47 \%$ of the carbon allocated to roots and mycorrhizal fungi can also be released to the soil microbial metabolism after root death (Fogel and Hunt, 1983). The main monoterpene sources are suggested to be degraded litter (Aaltonen et al., 2011; Faiola et al., 2014), while emitted VOCs strongly depend on litter type (Ramirez et al., 2010) and tree roots (Lin et al., 2007; Aaltonen et al., 2011, 2013), especially damaged ones (Hayward et al., 2001). Forest management can affect the soil isoprenoid fluxes. Clear-cut logging reduced soil VOC fluxes compared to non-disturbed forest soil (Paavolainen et al., 1998), but high monoterpene fluxes are also reported from stumps after a clear-cut (Haapanala et al., 2012). Mycorrhizal fungi also emit oxidized VOCs and small amounts of isoprenoids in a species-specific manner (Bäck et al., 2010). The microbial decomposition of organic matter produces VOCs in soil (Insam and Seewald, 2010; Greenberg et al., 2012). VOCs are often synthesized as side products (aerobic carbon metabolism, fermentation, amino acid degradation, terpenoid biosynthesis, and sulfur reduction) from primary metabolism and energy generation of decomposers (Peñuelas et al., 2014).

In addition to being released from living or decaying plant material and microorganisms, isoprenoids affect soil processes in multiple ways. Sesquiterpene signalling of mycorrhizal fungi was discovered to enhance root surface area for nutrient uptake and carbon availability for fungi as root exudates (Ditengou et al., 2015). VOCs can induce or reduce microbial activity (Asensio et al., 2012), control the population density of soil organisms (Wenke et al., 2010), and stimulate plant growth as fungal metabolites (Hung et al., 2013). Isoprenoids can inhibit nitrification and mineralization activity by being toxic for some microbes (Smolander et al., 2012), and some bacterial volatiles can have an antagonistic effect on plant pathogens (Kai et al., 2007) or can inhibit or stimulate the growth of soil fungal species (Mackie and Wheatley, 1999). Soil can also be a sink for isoprenoids (Insam and Seewald, 2010; Peñuelas et al., 2014), as some decomposers will also use VOCs as a carbon source (Greenberg et al., 2012). Soil enzymes can release substrates for metabolic VOC production (Mancuso et al., 2015), but isoprenoids can also inhibit enzyme activity in boreal forest soil (Adamczyk et al., 2015).

Soil VOC production processes have not been fully identified in field conditions, despite results showing that they may correspond to tens of percents of the boreal ecosystem flux (Aaltonen et al., 2013). Microbial VOC production depends on microbial community structure (Bäck et al., 2010), microbial biomass (Wieder et al., 2013), oxygen and nutrient availability (Insam and Seewald, 2010), the physiological state of decomposers (Insam and Seewald, 2010), and substrate quality (Stotzky et al., 1976). Freezing-thawing and dryingwetting events increase isoprenoid fluxes, as they contribute to organic-matter degradation (Asensio et al., 2007, 2008; Insam and Seewald, 2010; Aaltonen et al., 2013). Temperature affects VOC production (Asensio et al., 2007) indirectly through the temperature dependence of enzyme production and activity in VOC synthesis (Peñuelas and Staudt, 2010) and directly through volatilization, which is a function of temperature (Guenther et al., 1993). Enclosure techniques are a widely used method to measure soil gas fluxes (Pumpanen et al., 2004), and the enclosure temperature was shown to explain isoprenoid fluxes in a stronger way than soil temperature (Hayward et al., 2001; Aaltonen et al., 2013). Increasing temperature and decreasing soil water content contributed higher monoterpene volatilization from soil into the atmosphere (van Roon et al., 2005). Soil water content can also determine which microbial groups are most active (Veres et al., 2014). The flux rate depends on the compound. Monoterpenes are released from storage structures when temperaturedependent vapor pressure changes (Schurgers et al., 2009). High isoprenoid fluxes from soils are also measured after rain events (Greenberg et al., 2012).

This experiment was designed to determine whether carbon allocation to soil via roots affects soil isoprenoid fluxes through root metabolism and microbial activity, when the trenching approach was assumed to change the microbial communities between the different treatments. The aim was to identify isoprenoid sources, quantify isoprenoid fluxes and estimate the parameters regulating the isoprenoid fluxes based on the following hypotheses: (1) the presence of roots and mycorrhizal fungi enhances the amount of structurally non-bound (labile, e.g., fast turnover rate) carbon in the soil, which will increase isoprenoid fluxes. (2) Understorey vegetation is a sink of isoprenoids, as isoprenoids can be adsorbed 
on leaf surfaces. (3) A statistical model including prevailing temperature, seasonality, trenching treatments, understorey vegetation cover, above-canopy PAR, soil water content, and soil temperature can be used to estimate isoprenoid fluxes.

\section{Material and methods}

\subsection{Trenching experiment}

Measurements were executed in the southern boreal forest at the SMEAR II (Station for Measuring EcosystemAtmosphere Relations) station $\left(61^{\circ} 51^{\prime} \mathrm{N}, 24^{\circ} 17^{\prime} \mathrm{E}\right.$, 180 m a.s.l., above sea level) (Hari and Kulmala, 2005). The forest is a 55-year-old Scots pine stand (Pinus sylvestris), where Sorbus aucuparia, Betula pendula, and Picea abies grow below the canopy. Soil above the bedrock is Haplic podzol and soil depth is approximately $0.5-0.7 \mathrm{~m}$. The average thickness of the soil horizons from the SMEAR II stand is $6.0 \mathrm{~cm}$ (organic layer), $2.0 \mathrm{~cm}$ (E-horizon), and $16 \mathrm{~cm}$ (B-horizon). The stand was established by sowing after prescribed burning in 1962. Current canopy height is ca. $17 \mathrm{~m}$ and one-side leaf area index (LAI) is $2.0-2.5 \mathrm{~m}^{2} \mathrm{~m}^{-2}$ (Aalto et al., 2014). The stem basal area of all the trees was $24.3 \mathrm{~m}^{2} \mathrm{ha}^{-1}$ (Ilvesniemi et al., 2009). The understorey vegetation is formed by shrubs such as Vaccinium vitis-idaea, Vaccinium myrtillus, andCalluna vulgaris, mosses such as Pleurozium schreberi, Dicranum polysetum, and Dicranum scorparium, and Hylocomium splendens and grasses such as Deschampsia flexuosa and Melampyrum sylvaticum. Soil surface coverages of the different vascular and moss species on the experimental plots were determined using the eye estimation method in July 2015. Measurements were conducted on three replicate experimental sites $(1,2$, and 3 ) at the station. Site 1 is directed towards the east, site 2 towards the south-east, and site 3 towards the south-east. The distance between replicate sites was $50-100 \mathrm{~m}$. The experimental sites are described in more detail in Table 1.

The experimental setup was established in 2012 to study the effect of carbon allocation by tree roots and mycorrhizal fungi into soil. Each replicate site includes 20 experimental plots with different below- and aboveground treatments, which were implemented to regulate the carbon flow from trees and the understorey vegetation to soil microbes through roots and mycorrhizal fungi. Thirty-six of the experimental plots were measured in our study (Table 2). All the experimental plots were trenched by digging around a square volume $(0.9 \times 0.9 \mathrm{~m})$ of soil until reaching the bedrock, or to a depth of up to $40 \mathrm{~cm}$, and cutting roots between the experimental plot and the surrounding ground. Soil $\mathrm{C}$ input by plant allocation was controlled by comparing the soil, where the ingrowth of roots and mycorrhizal fungi and decomposer mobility was allowed (Control, 18 plots) to experimental plots where the ingrowth of tree roots and fungi was inhibited by placing isolating mesh $(1 \mu \mathrm{m})$ around the soil volume (code $\operatorname{Tr} 1,12$ plots). The treatment Tr50 (mesh size $50 \mu \mathrm{m}$, six plots) allowed access for microbes and mycorrhizal fungi, but prevented the ingrowth of tree roots (Table 2). Both meshes allowed water and nutrient exchange. As the understorey vegetation also allocates part of the photosynthetically produced $\mathrm{C}$ into the soil, the effect of the understorey vegetation was monitored by comparing plots with different vegetation: either the understorey vegetation was growing normally (marker,+ 21 plots), or vegetation was removed by cutting (marker,- 15 plots) (Table 2 ).

All plots at the SMEAR II stand were equipped with a $0.5 \mathrm{~m}$ long tube, where soil water content was measured using the capacity probe (PR2, Delta-T Devices) every second week. Soil temperature sensors were placed in the soil surface layer on each plot (depth $4 \mathrm{~cm}$ ), and data were logged every fourth hour from May to October in 2012-2015. Photosynthetically active radiation (PAR) was measured at the SMEAR II stand from a wavelength range of $400-700 \mathrm{~nm}$ using an LI-19OSZ quantum sensor (Li-Cor, Biosciences, Lincoln, NE) at heights of $18.0 \mathrm{~m}$ (above canopy) and $0.6 \mathrm{~m}$ (below canopy). The monthly total litterfall (needles, bark, twigs, and cones) and fraction of needles in the litterfall was determined once a month at the SMEAR II stand from April to October using 21 litter collectors (diameter $0.48 \mathrm{~m}$ ).

\subsection{Measurement methods}

The flux of isoprenoids from each plot was measured 56 times between 15 April and 23 October 2015. To analyze the seasonality of the isoprenoid fluxes, the results were pooled into six periods: (1) 15-24 April, (2) 30 April10 May, (3) 21 May-24 June, (4) 21 July-21 August, (5) 31 August-9 October, and (6) 19-23 October. The sequence of measurements was randomly arranged, to avoid any systematic errors in flux measurements between plots. The exact timing and sequence of the measurements are presented in Appendix A (Table A1).

Isoprenoid concentrations in the chamber headspace (height $40 \mathrm{~cm}$, chamber volume $10 \mathrm{~L}$ ) were measured with two dynamic (steady-state flow-through) glass chambers. The chambers were placed on permanent soil collars (height $7 \mathrm{~cm}$, diameter $21.7 \mathrm{~cm}$ ), which were placed on each plot in 2012. Incoming and outgoing air was sampled for 1.5$2 \mathrm{~h}$ using sampling flow $\left(0.1 \mathrm{~L} \mathrm{~min}^{-1}\right)$ through two Tenax TA Carbopack B adsorbent tubes, and the flux was calculated from the difference between ingoing and outgoing air (see Eq. 1). Filtered (active carbon trap and $\mathrm{MnO}_{2}-$ coated copper net) ambient air was continuously pumped $\left(1 \mathrm{~L} \mathrm{~min}^{-1}\right)$ into the chamber, and the chamber air volume was flushed for $0.5 \mathrm{~h}$ before sampling to stabilize the system. Chamber temperature was measured using a thermometer (Fluke 54II, Fluke, WA, USA) from $20-30 \mathrm{~cm}$ aboveground. Hemiterpenes (isoprene and 2-methyl butenol), monoterpenes ( $\alpha$-pinene, camphene, $\beta$-pinene, myrcene, $\Delta 3$-carene, p-cymene, limonene, and terpinolene, while oxy- 
Table 1. Soil depth $(\mathrm{cm})$ and soil surface coverages $(\%)$ of mosses, ericoid shrubs, grasses, and tree seedlings on the soil-vegetation interface $(+)$ and on bare soil, where vegetation was removed by cutting (-) on all experimental plots at three experimental sites $(1,2$, and 3$)$ in 2015. The standard error of the mean is given next to the mean.

\begin{tabular}{rrrrrrr}
\hline \multirow{2}{*}{ Site } & Vegetation & Soil depth & Mosses & Ericoid shrubs & Grasses & Tree seedlings \\
\hline 1 & + & $41.1(5.4)$ & $67.8(9.7)$ & $35.4(9.1)$ & $8.4(5.5)$ & $0.2(0.2)$ \\
& - & $45.3(3.3)$ & $20.1(6.5)$ & $0.2(0.1)$ & $0.0(0.0)$ & $0.0(0.0)$ \\
\hline 2 & + & $34.1(4.3)$ & $69.9(9.9)$ & $30.4(6.4)$ & $17.5(12.4)$ & $0.1(0.1)$ \\
& - & $46.4(5.5)$ & $17.1(2.4)$ & $0.0(0.0)$ & $0.1(0.0)$ & $0.0(0.0)$ \\
\hline 3 & + & $41.8(7.4)$ & $67.7(8.7)$ & $24.1(6.6)$ & $8.7(5.7)$ & $0.4(0.3)$ \\
& - & $43.7(3.8)$ & $16.1(7.5)$ & $2.4(2.1)$ & $0.1(0.0)$ & $0.0(0.0)$ \\
\hline
\end{tabular}

Table 2. Number $(N)$ of measured experimental plots on the different trenching treatments (Control: soil was non-trenched, Tr50: the ingrowth of mycorrhizal fungi was allowed, and $\operatorname{Tr} 1$ : decomposers were the only source) with vegetation $(+)$ and those with bare soil $(-)$ and the total number of plots.

\begin{tabular}{lrlrlr}
\hline Treatment & $N$ & Treatment & $N$ & Treatment & $N$ \\
\hline Control+ & 12 & Tr50+ & 3 & $\operatorname{Tr} 1+$ & 6 \\
Control- & 6 & Tr50- & 3 & $\operatorname{Tr} 1-$ & 6 \\
\hline & Total & 36 & & \\
\hline
\end{tabular}

gen containing 1.8-cineol and linalool are typically categorized for monoterpenes), and sesquiterpenes (longicyclene, iso-longifolene, $\beta$-caryophyllene, aromadendrene, and $\alpha$-humulene) were measured from the adsorbent tubes.

Tenax TA Carbopack B adsorbent tubes were kept in cold conditions $\left(5^{\circ} \mathrm{C}\right)$ and analyzed the week after sampling using a thermodesorption instrument (PerkinElmer TurboMatrix 650, Waltham, USA) connected to a gas chromatograph (PerkinElmer Clarus 600, Waltham, USA) with a DB-5MS $(60 \mathrm{~m}, 0.25 \mathrm{~mm}, 1 \mu \mathrm{m})$ column and a mass selective detector (PerkinElmer Clarus 600T, Waltham, USA). The sample tubes were thermally desorbed for $5 \mathrm{~min}\left(300^{\circ} \mathrm{C}\right)$, cryofocused in a Tenax cold trap operating at $-30^{\circ} \mathrm{C}$, and injected into the column using rapid heating $\left(300^{\circ} \mathrm{C}\right.$ ) (Aaltonen et al., 2011). The column was first heated from 50 to $150^{\circ} \mathrm{C}$ at the rate of $4^{\circ} \mathrm{C} \mathrm{min}^{-1}$ and then at the rate of $8^{\circ} \mathrm{C} \mathrm{min}^{-1}$ up to $250^{\circ} \mathrm{C}$, where it was kept for $5 \mathrm{~min}$. Total time of the analysis was $42.50 \mathrm{~min}$. Six standards in methanol solutions were used for calibration by injecting $(5 \mu \mathrm{L})$ into the sample tubes. Methanol was flushed away using nitrogen $\left(\mathrm{N}_{2}\right)$ flow of $80 \mathrm{~mL} \mathrm{~min}^{-1}$ through the Tenax TA Carbopack $\mathrm{B}$ adsorbent tubes for $10 \mathrm{~min}$. The uncertainty of analysis was $5-10 \%$ depending on the compound. The detection limit of the VOC quantification was $0.005-2.431 \mu \mathrm{g} \mathrm{m}^{-2} \mathrm{~h}^{-1}$ for the different isoprenoids.

\subsection{Flux calculations and statistical analyses}

The flux rates $\left(E, \mu \mathrm{g} \mathrm{m}^{-2} \mathrm{~h}^{-1}\right)$ of the different compounds were calculated for soil area (area inside to collar, $\mathrm{m}^{2}$ ) and time (h) using Eq. (1):

$E=\left(C_{\text {out }}-C_{\text {in }}\right) \frac{F_{\text {chamber }}}{1000} \frac{60}{A}$,

where $C_{\text {in }}$ is the concentration of ingoing air sample $\left(\mu \mathrm{g} \mathrm{m}^{-3}\right), C_{\text {out }}$ is the concentration of outgoing air sample $\left(\mu \mathrm{g} \mathrm{m}^{-3}\right), F_{\text {chamber }}\left(\mathrm{m}^{3} \mathrm{~min}^{-1}\right)$ is the flow rate of air pumped into the chamber, and $A\left(\mathrm{~m}^{2}\right)$ is the soil surface area inside the collar.

The detection limit (DL) of the VOC quantification was calculated for every compound and for every measurement week using Eq. (2):

$\mathrm{DL}=\left(k_{\text {mean }}\left(3 \sqrt{\frac{\sum\left(m_{\text {in }}-\overline{m_{\text {in }}}\right)^{2}}{n-1}}\right)\right) \frac{F_{\text {chamber mean }}}{1000} \frac{60}{A}$,

where $k_{\text {mean }}$ is the mean sampled air volume $\left(\mathrm{m}^{3}\right), c_{\text {in }}$ is the compound mass of ingoing air sample $\left(\mu \mathrm{g} \mathrm{m}^{-3}\right)$, $F_{\text {chamber mean }}\left(\mathrm{m}^{3} \mathrm{~min}^{-1}\right)$ is the mean flow rate of air pumped into the chamber, and $A\left(\mathrm{~m}^{2}\right)$ is the soil surface area inside the collar. Data were analyzed using MATLAB software (version 2015a, MathWorks, Natick, MA, USA), and statistical analyses were conducted using SPSS software (version 23, IBM SPSS Statistics; Chicago, IL, USA). The R Language and Environment for Statistical Computing program (version 3.2.4; R Core Team, 2016) was used to construct the mixed-effect linear models. A random permuted block design was used in our study with block sizes $3(\operatorname{Tr} 50+$ and $\operatorname{Tr} 50-), 6$ (Control-, $\operatorname{Tr} 1+, \operatorname{Tr} 1-)$, and 11 (Control+). The normality of sum monoterpene flux (sum of 10 monoterpenes), $\alpha$-pinene flux, chamber temperature, soil temperature, and soil volumetric water content were tested during six periods using the Kolmogorov-Smirnov and Shapiro-Wilk tests (degree of freedom: $60=$ Control+, $28=$ Control - , $17=\operatorname{Tr} 50+, 6=\operatorname{Tr} 50-, 28=\operatorname{Tr} 1+$, and $24=\operatorname{Tr} 1-) . \mathrm{We}$ also tested whether the annual total fluxes of different com- 
Table 3. Isoprenoid fluxes $\left(\mu \mathrm{g} \mathrm{m}{ }^{-2} \mathrm{~h}^{-1}\right)$ from the different trenching treatments (Control+ $(N=60)$, Control- $(N=28)$, Tr1+ $(N=28)$, $\operatorname{Tr} 1-(N=24), \operatorname{Tr} 50+(N=17)$, and $\operatorname{Tr} 50-(N=6))$ during periods $1-6,2015$. Fluxes are means (SE: standard error) of the whole data set. $\mathrm{BDL}=$ below detection limit of the VOC quantification. The effect of vegetation on fluxes between the plots with vegetation $(+)$ and those with bare soil $(-)$ was tested with the Kruskal-Wallis test $(p<0.05)$. Values were marked in bold if they differed between vegetation treatments. Significant differences in flux rates between the trenching treatments are indicated with different letters (Kruskal-Wallis test; $p<0.05)$.

\begin{tabular}{|c|c|c|c|c|c|c|}
\hline Flux & Control+ & Control- & $\operatorname{Tr} 50+$ & $\operatorname{Tr} 50-$ & $\operatorname{Tr} 1+$ & $\operatorname{Tr} 1-$ \\
\hline Isoprene & $1.60^{\mathrm{a}}(0.56)$ & $0.98^{\mathrm{a}}(0.33)$ & $4.43^{\mathrm{a}}(2.78)$ & $1.24^{\mathrm{a}}(0.93)$ & $4.91^{\mathrm{a}}(3.55)$ & $4.10^{\mathrm{a}}(2.27)$ \\
\hline \multicolumn{7}{|l|}{ Monoterpenes } \\
\hline$\alpha$-pinene & $14.68^{\mathrm{a}}(2.57)$ & $31.35^{\mathrm{b}}(6.93)$ & $21.98^{\mathrm{ac}}(8.41)$ & $26.35^{\mathrm{ab}}(11.15)$ & $11.53^{\mathrm{a}}(3.42)$ & $36.18^{\mathrm{bc}}(8.09)$ \\
\hline camphene & $1.70^{\mathrm{ac}}(0.23)$ & $4.34^{\mathrm{b}}(1.05)$ & $2.87^{\mathrm{ab}}(0.87)$ & $3.08^{\mathrm{abc}}(0.87)$ & $1.39^{\mathrm{c}}(0.39)$ & $3.07^{b}(0.55)$ \\
\hline$\beta$-pinene & $0.30^{\mathrm{a}}(0.06)$ & $0.70^{\mathrm{b}}(0.18)$ & $0.46^{\mathrm{ab}}(0.21)$ & $0.44^{\mathrm{ab}}(0.24)$ & $0.25^{\mathrm{a}}(0.08)$ & $0.53^{\mathrm{ab}}(0.14)$ \\
\hline myrcene & $0.09^{\mathrm{a}}(0.02)$ & $0.21^{\mathrm{b}}(0.06)$ & $0.19^{\mathrm{ab}}(0.10)$ & $0.18^{\mathrm{ab}}(0.09)$ & $0.14^{\mathrm{ab}}(0.04)$ & $0.23^{\mathrm{b}}(0.06)$ \\
\hline$\Delta 3$-carene & $5.41^{\mathrm{a}}(0.79)$ & $10.97^{b}(2.17)$ & $7.32^{\mathrm{ac}}(2.87)$ & $7.83^{\mathrm{ab}}(3.09)$ & $5.25^{\mathrm{a}}(1.64)$ & $8.57^{\mathrm{bc}}(1.44)$ \\
\hline p-cymene & $0.19^{\mathrm{ad}}(\mathbf{0 . 0 7})$ & $0.29^{\mathrm{b}}(0.05)$ & $0.16^{\mathrm{ac}}(0.06)$ & $0.13^{\mathrm{abc}}(0.04)$ & $0.13^{\mathrm{c}}(0.05)$ & $0.23^{\text {bd }}(0.04)$ \\
\hline limonene & $0.29^{\mathrm{a}}(0.05)$ & $0.49^{\mathrm{b}}(0.09)$ & $0.34^{\mathrm{ac}}(0.15)$ & $0.23^{\mathrm{ab}}(0.10)$ & $0.27^{\mathrm{a}}(0.09)$ & $0.44^{b c}(0.07)$ \\
\hline terpinolene & $0.05^{\mathrm{a}}(0.01)$ & $0.09^{b}(0.03)$ & $0.09^{\mathrm{ab}}(0.04)$ & $0.07^{\mathrm{ab}}(0.03)$ & $0.05^{\mathrm{a}}(0.02)$ & $0.09^{\mathrm{b}}(0.02)$ \\
\hline Sum of the monoterpenes & $22.87^{\mathrm{a}}$ & $48.62^{b}$ & $33.59^{\mathrm{ac}}$ & $38.43^{\mathrm{ab}}$ & $19.18^{\mathrm{a}}$ & $49.49^{\mathrm{bc}}$ \\
\hline \multicolumn{7}{|l|}{ Sesquiterpenes } \\
\hline longicyclene & $0.01^{\mathrm{a}}(0.002)$ & $0.01^{\mathrm{a}}(0.002)$ & $0.01^{\mathrm{a}}(0.004)$ & BDL & $0.01^{\mathrm{a}}(0.002)$ & $0.01^{\mathrm{a}}(0.002)$ \\
\hline$\beta$-caryophyllene & $0.24^{\mathrm{a}}(0.073)$ & $0.51^{\mathrm{a}}(0.273)$ & $0.39^{\mathrm{a}}(0.150)$ & $0.34^{\mathrm{a}}(0.317)$ & $0.38^{\mathrm{a}}(0.140)$ & $0.34^{\mathrm{a}}(0.106)$ \\
\hline aromadendrene & $0.07^{\mathrm{a}}(0.026)$ & $0.16^{\mathrm{a}}(0.093)$ & $0.10^{\mathrm{a}}(0.052)$ & BDL & $0.06^{\mathrm{a}}(0.023)$ & $0.07^{\mathrm{a}}(0.023)$ \\
\hline$\alpha$-humulene & $0.03^{\mathrm{a}}(0.010)$ & $0.06^{\mathrm{a}}(0.027)$ & $0.05^{\mathrm{a}}(0.022)$ & $0.06^{\mathrm{a}}(0.062)$ & $0.05^{\mathrm{a}}(0.021)$ & $0.03^{\mathrm{a}}(0.010)$ \\
\hline Sum of the sesquiterpenes & $0.35^{\mathrm{a}}$ & $0.73^{\mathrm{a}}$ & $0.55^{\mathrm{a}}$ & $0.42^{\mathrm{a}}$ & $0.50^{\mathrm{a}}$ & $0.45^{\mathrm{a}}$ \\
\hline
\end{tabular}

pounds from the trenching treatments were normally distributed. If the data were non-normally distributed, the nonparametric Kruskal-Wallis test (degree of freedom =1) at the significance level of $<0.05$ was used to determine whether the treatments were statistically different (Tables 3 and 4).

The effect of period, vegetation effect, trenching treatment, chamber temperature, above-canopy PAR, soil water content, soil $\mathrm{CO}_{2}$ flux, and soil temperature for total monoterpene, total sesquiterpene, and individual isoprenoid fluxes were tested using the mixed-effect linear models. For example, total monoterpene fluxes $(M)$ were modeled by the mixed-effect linear model:

$$
\begin{aligned}
M & =B_{0}+B_{\mathrm{s}}+B_{\mathrm{v}}+B_{\mathrm{c}} C+B_{\mathrm{sv}}+B_{\mathrm{sc}} C+B_{\mathrm{vc}} C \\
& +B_{\mathrm{svc}} C+\epsilon
\end{aligned}
$$

where $B_{0}$ denotes a fixed intercept parameter, $B_{\mathrm{s}}$ denotes fixed unknown parameters associated with season variable, $B_{\mathrm{v}}$ denotes fixed unknown parameters associated with vegetation effect variable, $B_{\mathrm{c}}$ denotes fixed unknown slope parameter related to chamber temperature $C, B_{\mathrm{sv}}$ denotes fixed parameters for interaction of period and vegetation, $B_{\mathrm{sc}}$ denotes fixed slope parameters for interaction of season and chamber temperature, $B_{\mathrm{vc}}$ denotes fixed slope parameters for the interaction of vegetation and chamber temperature, and $B_{\text {svc }}$ denotes fixed parameters for three-way interac- tion of period, vegetation, and chamber temperature. In the model (3), the error term $\in$ is assumed to have a form:

$\epsilon=\propto_{l}+\propto_{p}+u$

where $\propto_{l}$ denotes random parameters that are related to the trenching plot, $\propto_{p}$ denotes random parameters related to the measurement site $(1,2$, and 3$)$, and $u$ is an unobservable random error term. Random-effect parameters and random-error term are assumed to follow normal distributions $\propto_{l} \sim N\left(0, \sigma_{l}^{2}\right), \propto_{p} \sim N\left(0, \sigma_{p}^{2}\right)$, and $u \sim N\left(0, \sigma_{u}^{2}\right)$, respectively.

Similar types of mixed models with different variable combinations (factor variables are period, vegetation effect, and trenching treatment, and numerical variables are chamber temperature, above-canopy PAR, soil water content, soil $\mathrm{CO}_{2}$ flux, and soil temperature) were used to model total sesquiterpene fluxes and individual isoprenoid fluxes (Tables 5 and 6).

\section{Results}

Hemiterpenes (isoprene), monoterpenes ( $\alpha$-pinene, camphene, $\beta$-pinene, myrcene, $\Delta 3$-carene, $\mathrm{p}$-cymene, limonene, and terpinolene), and sesquiterpenes (longicyclene, $\beta$ - 
Table 4. Mean (SE) total monoterpene and $\alpha$-pinene fluxes $\left(\mu \mathrm{g} \mathrm{m}^{-2} \mathrm{~h}^{-1}\right)$ from different treatments $(\mathrm{Control}+$, Control-, Tr50+, Tr50-, Tr1+ and Tr1-) during periods 1 to 6, 2015. The periods are (1) 15-24 April, (2) 30 April to 10 May, (3) 21 May to 24 June, (4) 21 July to 21 August, (5) 31 August to 9 October, and (6) 19-23 October. Values were denoted by different letters (a, b, and c) if they differed between treatments within the certain time period (Kruskal-Wallis test; $p<0.05$ ).

\begin{tabular}{lrrrrrr}
\hline Period & Control+ & Control- & Tr50+ & Tr50- & Tr1+ & Tr1- \\
\hline \multicolumn{7}{c}{ Monoterpenes } \\
\hline 1 & $13.0(5.8)$ & $30.5(2.7)$ & - & - & $10.2(9.8)$ & - \\
2 & $17.9(5.5)$ & $16.6(6.2)$ & $37.5(31.7)$ & $5.4(-)$ & $5.1(1.8)$ & $18.1(11.8)$ \\
3 & $21.4(6.9)$ & $52.4(25.9)$ & $58.4(46.5)$ & - & $34.4(21.8)$ & $39.9(10.2)$ \\
4 & $13.8^{\mathrm{a}}(3.4)$ & $48.0^{\mathrm{b}}(11.9)$ & $15.4(9.6)$ & $2.0(-)$ & $18.6(10.2)$ & $39.5^{\mathrm{b}}(11.8)$ \\
5 & $44.8(12.8)$ & $78.0(31.7)$ & $32.7(15.7)$ & $51.3(22.8)$ & $24.5(8.4)$ & $67.1(33.4)$ \\
6 & $19.3^{\mathrm{a}}(3.8)$ & $36.9(9.0)$ & $7.6(1.5)$ & $69.2(-)$ & $8.6^{\mathrm{b}}(2.9)$ & $73.5^{\mathrm{c}}(25.4)$ \\
\hline \multicolumn{7}{c}{$\alpha-$ pinene } \\
\hline 1 & $7.0(3.1)$ & $16.8(1.0)$ & - & - & $7.9(7.6)$ & \\
2 & $10.7(3.5)$ & $6.7(2.8)$ & $20.4(19.4)$ & $0.6(-)$ & $2.1(0.9)$ & $11.5(7.6)$ \\
3 & $13.0(4.3)$ & $31.7(16.6)$ & $38.3(31.1)$ & - & $21.1(13.5)$ & $25.3(7.3)$ \\
4 & $7.6^{\mathrm{a}}(2.2)$ & $30.9^{\mathrm{b}}(8.9)$ & $9.2(6.8)$ & $0.8(-)$ & $7.9^{\mathrm{a}}(4.3)$ & $28.2^{\mathrm{b}}(9.6)$ \\
5 & $31.8(9.4)$ & $55.1(22.9)$ & $24.3(12.2)$ & $35.7(16.4)$ & $17.7(6.4)$ & $50.0(25.6)$ \\
6 & $13.2^{\mathrm{a}}(2.6)$ & $26.5(6.9)$ & $5.3(1.0)$ & $49.6(-)$ & $5.4^{\mathrm{a}}(1.7)$ & $60.2^{\mathrm{b}}(22.8)$ \\
\hline
\end{tabular}

caryophyllene, aromadendrene, and $\alpha$-humulene) were measured from the different treatments. Monoterpene flux range was $0.40-221.0 \mu \mathrm{g} \mathrm{m}^{-2} \mathrm{~h}^{-1}$ (data not shown). The most dominating compounds were $\alpha$-pinene, camphene, $\beta$-pinene, and $\Delta^{3}$-carene, covering $84-94 \%$ of the flux spectra (Table 3). The exception was $\operatorname{Tr} 1+$, where isoprene covered $20 \%$ of the spectrum (Table 3). Sesquiterpene flux range was $0.01-10.9 \mu \mathrm{g} \mathrm{m}^{-2} \mathrm{~h}^{-1}$ (data not shown). Sesquiterpene fluxes from various sources were equally low $(0.35-$ $0.73 \mu \mathrm{g} \mathrm{m}^{-2} \mathrm{~h}^{-1}$ ), and the most abundant sesquiterpenes emitted were $\beta$-caryophyllene and aromadendrene (Table 3). Isoprene fluxes from the different sources were also low $\left(0.98-4.91 \mu \mathrm{g} \mathrm{m}^{-2} \mathrm{~h}^{-1}\right)$ (Table 3) and flux range was 0.005$99.8 \mu \mathrm{g} \mathrm{m}^{-2} \mathrm{~h}^{-1}$ (data not shown).

\subsection{Correlations of temperature, soil moisture, and PAR with VOC measurements}

At the experimental sites, soil water content, and chamber and soil temperature were measured to observe their influence on the fluxes. Daily temperature followed PAR (Fig. 1a). Chamber, soil, and ambient temperatures followed very similar patterns. The median difference between chamber and soil temperature was $3.6^{\circ} \mathrm{C}$, and the median difference between chamber and ambient temperature was $0.9^{\circ} \mathrm{C}$. Water content was $0.06-0.45 \mathrm{~m}^{3} \mathrm{~m}^{-3}$ in the mineral soil (Fig. 1c), and it was higher from April to the end of July and very low from August to the end of October. During the measurements PAR was $10-1440 \mu \mathrm{mol} \mathrm{m}^{-2} \mathrm{~s}^{-1}$ above the canopy and $1-410 \mu \mathrm{mol} \mathrm{m}^{-2} \mathrm{~s}^{-1}$ below the canopy (Fig. 1b). Chamber and soil temperature did not differ between treatments, except during July and August (period 4), when soil temperature was higher in Control $-\left(13.5^{\circ} \mathrm{C}\right)$, where
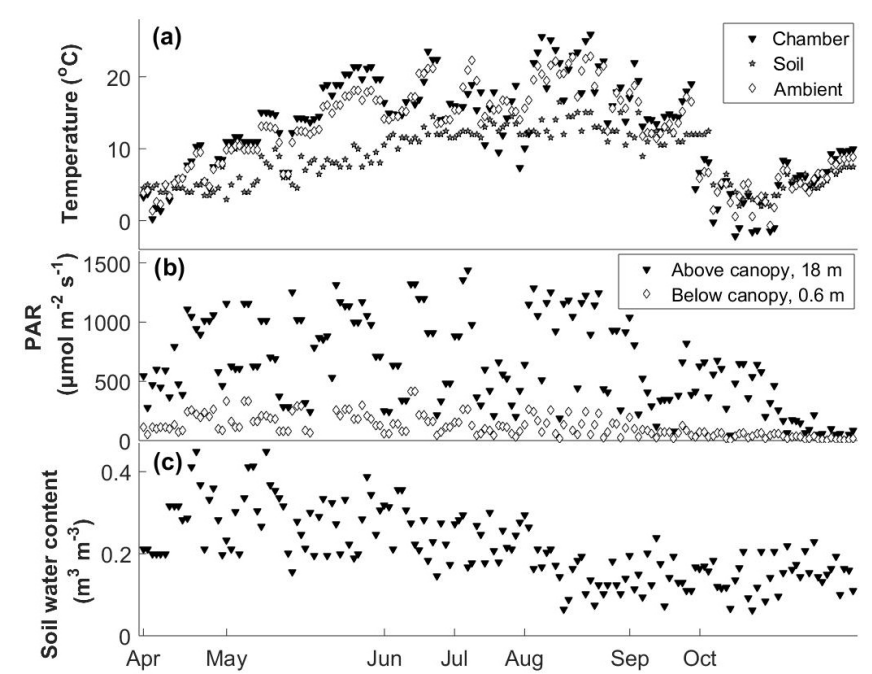

Figure 1. Environmental parameters during the measurements from 15 April to 23 October 2015. (a) Chamber, soil, and ambient temperature $\left({ }^{\circ} \mathrm{C}\right)$. (b) Photosynthetically active radiation (PAR, $\mu \mathrm{mol} \mathrm{m} \mathrm{m}^{-2} \mathrm{~s}^{-1}$ ) above and below the canopy. (c) Soil water content $\left(\mathrm{m}^{3} \mathrm{~m}^{-3}\right)$.

the ingrowth of roots and mycorrhizal fungi was allowed without understorey vegetation cover, than in Control+ $\left(12.6^{\circ} \mathrm{C}\right)$ with understorey vegetation cover. Soil water content was higher in Control $+\left(0.13 \mathrm{~m}^{3} \mathrm{~m}^{-3}\right)$ than in Control$\left(0.10 \mathrm{~m}^{3} \mathrm{~m}^{-3}\right)$ and higher in $\operatorname{Tr} 1-\left(0.19 \mathrm{~m}^{3} \mathrm{~m}^{-3}\right.$, only decomposer activity was allowed without understorey vegetation cover) compared to Control+ and Control- in September and early October (period 5) (data not shown). 

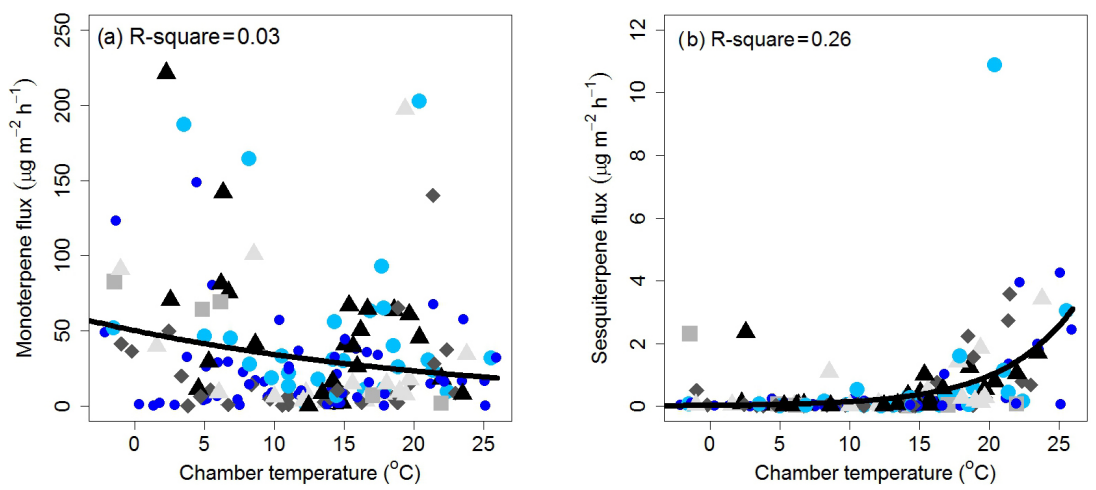

Figure 2. Relationship between monoterpene $\left(\mathbf{a}, R^{2}=0.03, p\right.$ value $\left.<0.01\right)$ and sesquiterpene $\left(\mathbf{b}, R^{2}=0.26, p\right.$ value $\left.>0.05\right)$ fluxes $\left(\mu \mathrm{g} \mathrm{m}^{-2} \mathrm{~h}^{-1}\right)$ and chamber temperature, presented as combined data from the different treatments (Control: soil was non-trenched, Tr50: the ingrowth of mycorrhizal fungi was allowed, and $\operatorname{Tr} 1$ : decomposers were the only source) with vegetation $(+)$ and those with bare soil $(-)$. The treatments $($ Control $+=$ small blue circle, Control $-=$ solid blue circle, $\operatorname{Tr} 50+=$ filled gray triangle point-up, Tr50 $-=$ filled gray square, $\operatorname{Tr} 1+=$ filled gray diamond, and $\operatorname{Tr} 1-=$ filled black triangle point-up) were measured during periods $1-6,2015$.

Temperature dependence of monoterpene and sesquiterpene fluxes were determined by combining all the measurements. Sesquiterpene fluxes showed exponential correlation with chamber temperature $\left(R^{2}=0.26, p<0.001\right.$, Fig. 2a). Monoterpene fluxes did not correlate with chamber temperature $\left(R^{2}=0.03, p>0.05\right.$, Fig. $\left.2 \mathrm{~b}\right)$.

Monoterpene fluxes from the Tr50 plots (ingrowth of decomposers and mycorrhizal fungi) were higher when chamber temperatures were lower $\left(R^{2}=0.91, p<0.01\right)$, but in all other treatments the effects were not significant $(p>0.05)$ (Appendix A Fig. A2).

We also analyzed the effects of soil water content and temperature, chamber temperature, $\mathrm{PAR}$, and soil $\mathrm{CO}_{2}$ flux on monoterpene and sesquiterpene fluxes from all the treatments. Although we observed some statistically significant differences, the $R^{2}$ values were very small, varying from 0.00 to 0.08 (Appendix A Fig. A1).

\subsection{Different VOC sources in soil}

Understorey vegetation was a monoterpene sink, since isoprenoid fluxes measured on bare soil were higher than fluxes measured on soil with vegetation cover in different treatments. The sum of the monoterpene fluxes was highest from the bare soil, where the soil was non-trenched (Control-) or where roots and mycorrhizal hyphae were excluded and decomposers were the only active microbes $(\operatorname{Tr} 1-)$. On the contrary, the sum of the monoterpene fluxes did not differ between bare soil and soil with vegetation cover, where the ingrowth of mycorrhizal fungi was allowed (Tr50) (Table 3).

Isoprenoid fluxes were compared between the treatments in the six periods. The mean total monoterpene flux from the treatments was $2.0-78.0 \mu \mathrm{g} \mathrm{m}^{-2} \mathrm{~h}^{-1}$ and the mean total $\alpha$-pinene flux was $0.6-60.2 \mu \mathrm{g} \mathrm{m}^{-2} \mathrm{~h}^{-1}$ (Table 4), with high temporal variation. However, the presence of vegetation and decomposer activity clearly affected the fluxes in July-August (period 4) and October (period 6) (Table 4). In July-August, the presence of vegetation $($ Control+) significantly decreased the total monoterpene and $\alpha$-pinene fluxes compared to both Controland $\operatorname{Tr} 1-\left(\right.$ Control $-: p_{\text {monoterpenes }}=0.015$ and $p_{\alpha \text {-pinene }}=$ $0.011 ; \operatorname{Tr} 1-: p_{\text {monoterpenes }}=0.027$ and $\left.p_{\alpha \text {-pinene }}=0.035\right)$. In October, the decomposer-only treatment $(\operatorname{Tr} 1-)$ had significantly higher fluxes than Control+ $\left(p_{\text {monoterpenes }}=0.027\right.$ and $\left.p_{\alpha \text {-pinene }}=0.027\right)$ and $\operatorname{Tr} 1+\left(p_{\text {monoterpenes }}=0.034\right.$ and $\left.p_{\alpha \text {-pinene }}=0.034\right)$.

\subsection{Seasonality of VOC fluxes}

Seasonal variations of monoterpene, sesquiterpene, and isoprene fluxes were determined from non-trenched soil with vegetation (Control+). Monoterpene, sesquiterpene, and isoprene fluxes varied between $0-149,0-4$, and 0 $29 \mu \mathrm{g} \mathrm{m}^{-2} \mathrm{~h}^{-1}$, respectively (Fig. 3). Monoterpene fluxes were highest in October and lowest in mid-April, but as shown in Fig. A2, they correlated poorly with soil temperature. Soil temperature was close to $0^{\circ} \mathrm{C}$ in early October and between 1 and $5^{\circ} \mathrm{C}$ in mid-April (Fig. 3). Sesquiterpene fluxes were highest in summer. Isoprene fluxes were highest in June and July when temperature and PAR was high (Fig. 3), but interestingly high isoprene fluxes were also observed in October, when temperature and PAR was low.

Average total monoterpene fluxes were highest from nontrenched and bare soil in September-October (period 5), and from bare soil with decomposers in October (period 6) (Table 4). As shown in Fig. 4, the flux rates correlate with total litterfall and the fraction of needles in the litterfall. As shown in Fig. 3, the effect of litterfall on monoterpene flux rates occurs after a short delay in October. Monthly total litterfall $\left(8.7-114.2 \mathrm{~g} \mathrm{~m}^{-2}\right)$ and the total amount of needles in the litterfall (1.6-99.7 $\mathrm{g} \mathrm{m}^{-2}$ ) varied at the SMEAR II stand from April to October 2015 (Fig. 4). Monthly total and needle lit- 


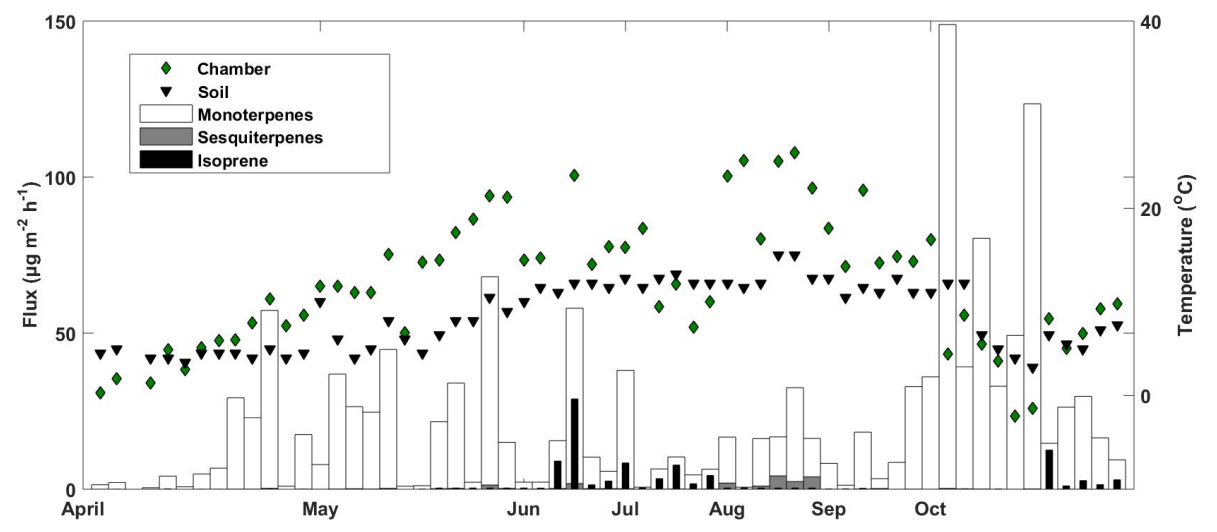

Figure 3. Monoterpene, sesquiterpene, and isoprene fluxes $\left(\mu \mathrm{g} \mathrm{m}^{-2} \mathrm{~h}^{-1}\right)$, as well as chamber and soil temperatures $\left({ }^{\circ} \mathrm{C}\right)$ from a non-trenched forest floor (Control+) during April-October 2015.

Table 5. Results from the mixed-effect linear models, testing the factors impacting monoterpene and sesquiterpene fluxes from boreal forest soil $(N$ (all treatments $)=163, N($ plot $)=36, N$ (site) $=3$ ). Tested effects: period $(1-6)$, vegetation $( \pm)$, chamber temperature $($ chamber temp), soil temperature (soil temp), PAR, soil water content (soil wt), and the interactions of these. Random effects were related to trenching plot number and trenching site. Pseudo- $R^{2}$ was calculated based on Nakagawa and Schielzeth (2013) and Johnson (2014).

\begin{tabular}{|c|c|c|c|}
\hline \multicolumn{4}{|c|}{ Monoterpenes } \\
\hline Fixed effects & Chisq value & $p$ value & Pseudo- $R^{2}$ \\
\hline factor (period) & 16.762 & $0.004975^{\mathrm{b}}$ & 0.43 \\
\hline factor (vegetation) & 12.52 & $0.0004026^{\mathrm{c}}$ & \\
\hline chamber temp & 7.7944 & $0.005241^{b}$ & \\
\hline period $^{\mathrm{a}}$ vegetation & 6.9411 & 0.2251 & \\
\hline period $^{\mathrm{a}}$ chamber temp & 27.771 & $4.035 \times 10^{-5, \mathrm{c}}$ & \\
\hline vegetation $^{\mathrm{a}}$ chamber temp & 4.5996 & $0.03198^{\mathrm{a}}$ & \\
\hline period $^{\text {a }}$ vegetation ${ }^{\mathrm{a}}$ chamber temp & 5.3451 & 0.3752 & \\
\hline \multicolumn{4}{|c|}{ Sesquiterpenes } \\
\hline Fixed effects & Chisq value & $p$ value & Pseudo- $R^{2}$ \\
\hline factor (period) & 7.0716 & 0.2154 & 0.29 \\
\hline chamber temp & 6.8436 & $0.008896^{\mathrm{b}}$ & \\
\hline period $^{\mathrm{a}}$ chamber temp & 22.44 & $0.0004318^{\mathrm{c}}$ & \\
\hline
\end{tabular}

Level of significance: ${ }^{\mathrm{a}} p$ value $<0.05,{ }^{\mathrm{b}} p$ value $<0.01$, and ${ }^{\mathrm{c}} p$ value $<0.001$.

terfall were 75-92 and 84-98\% higher in September, and 58-87 and 66-97\% higher in October, respectively, compared to the spring and summer months $(p<0.001)$, but total litterfall was also high in July (Fig. 4).

\subsection{Mixed-effect model results}

Mixed-effect linear models were used to determine which parameters are best in estimating the flux rates of monoterpenes and sesquiterpenes from boreal forest soil. The best fit was obtained with a combination of several biological and abiotic parameters. The presence of vegetation cover, measurement timing (period) and chamber temperature explained $43 \%$ of the individual monoterpene fluxes $(p<0.05)$, whereas measurement timing (period) and chamber temperature explained
$29 \%$ of the individual sesquiterpene fluxes $(p<0.01)$ (Table 5). The effect of the trenching treatment, PAR, soil water content, soil temperature, and soil $\mathrm{CO}_{2}$ flux were also tested, but their effects were non-significant $(p>0.05)$.

Mixed-effect linear models were also used to determine which parameters are best in estimating the flux rates of different individual isoprenoids. When the model included chamber temperature, vegetation effect, seasonality (period), and the interaction of these parameters, it explained $34-46 \%$ of the individual $\alpha$-pinene, camphene, $\beta$-pinene, and $\Delta 3$ carene fluxes (Table 6). When the model included seasonality, chamber temperature, soil water content, and the interaction of these, it was able to explain $40 \%$ of the variation within the longicyclene fluxes (Table 6). Chamber tempera- 


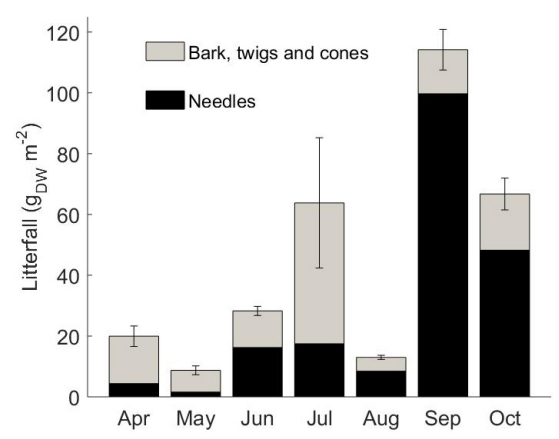

Figure 4. Monthly litterfall of bark, twigs, and cones (grey, $\mathrm{g}(\mathrm{DW}) \mathrm{m}^{-2}$ ), and the fraction of needles in litterfall (black, $\mathrm{g}(\mathrm{DW}) \mathrm{m}^{-2}$ ) at the SMEAR II stand from April to October 2015. Error bars indicate the standard error of monthly total litterfall from 21 litter collectors.

ture, seasonality, and the interaction of these, explained $35 \%$ of the variation within the $\alpha$-humulene fluxes. Seasonality, soil temperature, soil water content, and the interaction of these were able to estimate $35 \%$ of the variation within the isoprene fluxes (Table 6).

\section{Discussion}

Identifying the sources of isoprenoid fluxes from forest understorey vegetation and soil-in-field conditions is challenging, as most measurement techniques only yield net exchange (including all sources and sinks). The only way to dissect various processes is to manipulate the system, which was done here during the trenching treatment and vegetation removal. With the presented trenching experiment, where soil biological processes could be separated into different components, it was possible to separately analyze the fluxes originating from the decomposer, mycorrhizal fungal, tree roots, and understorey vegetation individually for the first time. First, we tested whether the photosynthesized carbon allocation to the soil affects the isoprenoid production of different soil organisms (decomposers, mycorrhizal fungi, and roots). Second, we analyzed how important the vegetation is as a sink. Third, we aimed to construct a statistical model including prevailing temperature, seasonality, trenching treatments, understorey vegetation cover, above-canopy PAR, soil water content, and soil temperature to estimate isoprenoid fluxes.

\subsection{Seasonality and carbon source impacts on emission rates and spectra}

Our results show that the seasonality of emissions is largely correlated to litterfall, especially for monoterpenes, and our results confirm the emission spectrum and temporal variation of isoprenoids from the boreal forest understorey and soil layer found by Hellén et al. (2006) and Aaltonen et al. (2011,
2013). Earlier studies have also suggested that litter and decomposers are important isoprenoid sources (Hayward et al., 2001; Asensio et al., 2007, 2008; Isidorov et al., 2010; Insam and Seewald, 2010; Aaltonen et al., 2013; Greenberg et al., 2012; Faiola et al., 2014). Monoterpenes can be produced simultaneously by MEP pathways in plastids and by MVK pathways in cytoplasm, and at least some fungi and bacteria are capable of activating the MEP pathway (Rohmer et al., 1993, 1996; Eisenreich et al., 1998; Walter et al., 2000; Banerjee and Sharkey, 2014). Soil can also absorb $80 \%$ of litter-produced VOCs (Ramirez et al., 2010), when soil and litter samples from a Pinus taeda stand on a loamy sand soil (pH 3.6, $50 \%$ of the water holding capacity) were studied in a laboratory.

The litterfall amount reflects the stand density and dominating tree species of the forest canopy and, indirectly, the size of forest carbon storage. VOC release from the fresh litter appears to be important, as the highest isoprenoid fluxes were measured in October, correlating with litterfall (especially needle) production. Decomposition releases isoprenoids from needle storages (Aaltonen et al., 2011), and litter emissions are regulated by microbial activity, i.e., soil respiration, microbial biomass, carbon availability, temperature, and rain events (Leff and Fierer, 2008; Greenberg et al., 2012). Old litter can also be an important isoprenoid source during the following year, as the degradation of Scots pine litter is a slow process (Kainulainen and Holopainen, 2002). Decomposition can continue in soil under snow cover, and isoprenoids are released after snowmelt (Aaltonen et al., 2011). Isoprenoids can also be released after non-enzymatic, thermo-chemical reactions (Greenberg et al., 2012), and soil processes can also be efficient isoprenoid sources during wintertime (Aaltonen et al., 2012). Litterfall contribution to decomposition processes is generally considerable, as the decomposition of fresh litter requires less energy than the decomposition of non-labile organic compounds. The quantity of carbon and its decomposability also decreases with litter age (Greenberg et al., 2012).

Contrary to our hypothesis, belowground carbon availability did not clearly affect emissions, as only minor differences were observed between the trenching treatments. This is a significant finding and indicates that despite microbial communities most probably being very different in various trenching treatments, community changes do not significantly affect the net VOC flux from soils. We propose that the reason for this is that VOCs used for microbial signalling (e.g., Wenke et al., 2010; Ditengou et al., 2015) are produced in low concentrations and therefore they cannot be seen in the soil net VOC flux. One theory for this would be that the presence of tree roots and plant-derived carbon flow favors microbes that are able to use VOCs as an energy source (Greenberg et al., 2012). However, we were unable to investigate either the microbial community structure or their VOC signalling in our study. As a conclusion, we may say that soil 
Table 6. Results from the mixed-effect linear models, testing the factors impacting isoprenoid fluxes from boreal forest soil $(N$ [all treatments $]=163, N$ [plot $]=36, N$ [site] $=3$ ). Tested effects: period (1-6), vegetation $( \pm)$, chamber temperature (chamber temp), soil temperature (soil temp), PAR, soil water content (soil wt), and the interactions of these. Random effects were related to trenching plot number and trenching site. Pseudo- $R^{2}$ was calculated based on Nakagawa and Schielzeth (2013), and Johnson (2014).

\begin{tabular}{|c|c|c|c|c|c|c|}
\hline Fixed effects: & Chisq value & $p$ value & Pseudo- $R^{2}$ & Chisq value & $p$ value & Pseudo- $R^{2}$ \\
\hline & \multicolumn{6}{|c|}{ Monoterpenes } \\
\hline & \multicolumn{3}{|c|}{$\alpha$-Pinene } & \multicolumn{3}{|c|}{ Camphene } \\
\hline factor (period) & 20.206 & $0.001143^{b}$ & 0.46 & 10.281 & 0.06764 & 0.44 \\
\hline factor (vegetation) & 13.086 & $0.0002975^{\mathrm{c}}$ & & 11.928 & $0.000553^{\mathrm{c}}$ & \\
\hline chamber temp & 11.28 & $0.0007833^{\mathrm{c}}$ & & 0.8389 & 0.3597 & \\
\hline period $^{\mathrm{a}}$ vegetation & 8.7498 & 0.1195 & & 1.1673 & 0.948 & \\
\hline period $^{\mathrm{a}}$ chamber temp & 25.809 & $9.717 \times 10^{-5, \mathrm{c}}$ & & 28.527 & $2.87 \times 10^{-5, \mathrm{c}}$ & \\
\hline vegetation ${ }^{\mathrm{a}}$ chamber temp & 5.4705 & $0.01934^{\mathrm{a}}$ & & 1.0471 & 0.3062 & \\
\hline \multirow[t]{2}{*}{ period $^{\mathrm{a}}$ vegetation ${ }^{\mathrm{a}}$ chamber temp } & & 0.3903 & & 11.508 & $0.04219^{\mathrm{a}}$ & \\
\hline & & $\beta$-Pinene & & & $\Delta 3$-Carene & \\
\hline factor (period) & 25.781 & $9.841 \times 10^{-5, \mathrm{c}}$ & \multirow[t]{7}{*}{0.39} & 9.6409 & 0.08607 & \multirow[t]{7}{*}{0.34} \\
\hline factor (vegetation) & 7.8661 & $0.005037^{\mathrm{b}}$ & & 7.169 & $0.007417^{b}$ & \\
\hline chamber temp & 6.6896 & $0.009697^{\mathrm{b}}$ & & 1.7575 & 0.1849 & \\
\hline period $^{\mathrm{a}}$ vegetation & 7.0668 & 0.2157 & & 5.0279 & 0.4125 & \\
\hline period $^{\mathrm{a}}$ chamber temp & 21.477 & $0.000658^{\mathrm{c}}$ & & 27.831 & $3.927 \times 10^{-5, \mathrm{c}}$ & \\
\hline vegetation $^{\mathrm{a}}$ chamber temp & 3.2511 & 0.07138 & & 2.6246 & 0.1052 & \\
\hline period $^{\mathrm{a}}$ vegetation ${ }^{\mathrm{a}}$ chamber temp & 6.391 & 0.27 & & 3.0477 & 0.6926 & \\
\hline \multicolumn{4}{|c|}{ Limonene } & & & \\
\hline factor (period) & 11.947 & $0.03552^{\mathrm{a}}$ & \multirow[t]{7}{*}{0.38} & & & \\
\hline PAR & 5.407 & $0.02006^{\mathrm{a}}$ & & & & \\
\hline chamber temp & 0.2088 & 0.6477 & & & & \\
\hline period $^{\mathrm{a}}$ PAR & 12.302 & $0.03087^{\mathrm{a}}$ & & & & \\
\hline period $^{\mathrm{a}}$ chamber temp & 5.542 & 0.3534 & & & & \\
\hline PAR $^{\mathrm{a}}$ chamber temp & 5.9393 & $0.01481^{\mathrm{a}}$ & & & & \\
\hline period $^{\mathrm{a}} \mathrm{PAR}^{\mathrm{a}}$ chamber temp & 8.4248 & 0.1343 & & & & \\
\hline
\end{tabular}

\begin{tabular}{|c|c|c|c|c|c|c|}
\hline & \multicolumn{6}{|c|}{ Sesquiterpenes } \\
\hline & \multicolumn{3}{|c|}{ Longicyclene } & & & \\
\hline factor (period) & 13.364 & $0.0202^{\mathrm{a}}$ & 0.40 & & & \\
\hline soil wt & 4.2641 & $0.03893^{\mathrm{a}}$ & & & & \\
\hline chamber temp & 8.8191 & $0.002981^{\mathrm{b}}$ & & & & \\
\hline period $^{\mathrm{a}}$ soil $\mathrm{wt}$ & 0.8172 & 0.9759 & & & & \\
\hline period $^{\mathrm{a}}$ chamber temp & 21.212 & $0.0007388^{c}$ & & & & \\
\hline soil $\mathrm{wt}^{\mathrm{a}}$ chamber temp & 5.403 & $0.0201^{\mathrm{a}}$ & & & & \\
\hline \multirow[t]{2}{*}{ period $^{\mathrm{a}}$ soil wt $\mathrm{w}^{\mathrm{a}}$ chamber temp } & 9.9874 & 0.07559 & & & & \\
\hline & \multicolumn{3}{|c|}{$\alpha$-Humulene } & \multicolumn{3}{|c|}{$\beta$-Caryophyllene } \\
\hline factor (period) & 11.38 & $0.04434^{\mathrm{a}}$ & 0.35 & 5.9382 & 0.3123 & 0.31 \\
\hline chamber temp & 3.5212 & 0.06059 & & 6.0838 & $0.01364^{\mathrm{a}}$ & \\
\hline \multirow[t]{2}{*}{ period $^{\mathrm{a}}$ chamber temp } & 22.849 & $0.0003608^{c}$ & & 21.981 & $0.0005279^{c}$ & \\
\hline & \multicolumn{6}{|c|}{ Isoprene } \\
\hline factor (period) & 5.5947 & 0.3477 & 0.35 & & & \\
\hline soil wt & 1.077 & 0.2994 & & & & \\
\hline soil temp & 5.4103 & $0.02002^{\mathrm{a}}$ & & & & \\
\hline period $^{\mathrm{a}}$ soil wt & 10.32 & 0.06665 & & & & \\
\hline period $^{\mathrm{a}}$ soil temp & 25.991 & $8.958 \times 10^{-5, c}$ & & & & \\
\hline soil wt ${ }^{\mathrm{a}}$ soil temp & 0.1811 & 0.6705 & & & & \\
\hline period $^{\mathrm{a}}$ soil $\mathrm{wt}^{\mathrm{a}}$ soil temp & 15.851 & $0.007282^{\mathrm{b}}$ & & & & \\
\hline
\end{tabular}

Level of significance: ${ }^{\mathrm{a}} p$ value $<0.05,{ }^{\mathrm{b}} p$ value $<0.01$, and ${ }^{\mathrm{c}} p$ value $<0.001$. 
VOC fluxes are likely regulated by other processes than those directly dependent on plant-derived $\mathrm{C}$ flow into soil via roots.

In addition to litterfall, seasonal temperature variations also had an effect, especially on the sesquiterpene emissions. This was expected, as temperature can regulate isoprenoid emissions through physical processes (volatility and diffusion) and the enzyme activity of VOC synthesis (Peñuelas and Staudt, 2010). The traditional approach for modeling isoprenoid emissions is to use the so-called Guenther algorithm (Guenther et al., 1991, 1993, 1995), which calculates individual plant- or ecosystem-scale emission rates according to prevailing temperature. The global emission model MEGAN (Model of Emissions of Gases and Aerosols from Nature) was developed based on the Guenther algorithm, and the model includes plant functional type, long-term temperature response, leaf age, and soil water content (Guenther et al., 2006, 2012). Often this is a good approximation for forest ecosystem- or global-scale inventories of biogenic VOC emissions (Grote and Niinemets, 2008; Sindelarova et al., 2014; Chatani et al., 2015). However, the effects of temperature on emissions from soil are not straightforward, as the soil biological activity is very different between spring and autumn, although air or soil temperatures may be very similar. This was clearly seen in our results. Sesquiterpenes are known to be signalling compounds between the roots and ectomycorrhizal fungi (Ditengou et al., 2015), and this signalling could be stronger during active periods of the tree. Sesquiterpene flux rates were small in our study, possibly as they can react in the topsoil, or on leaf surfaces before they are released into the chamber headspace. Sesquiterpene volatilization also requires a higher temperature than the volatilization of monoterpenes, and the adsorption of sesquiterpenes on leaf and chamber surfaces is more likely than monoterpene adsorption. Other effects of carbon availability on isoprenoid fluxes were not confirmed.

\subsection{Effect of understorey vegetation on VOC fluxes}

The most important contributing factor to net flux from the forest floor during the entire growing period seems to be the vegetation cover, which was discovered to be a sink for isoprenoids. The difference in total monoterpene fluxes between the vegetated and bare soil plots was largest in JulyAugust (soil with decomposers only, 8.5-fold) and in midOctober (non-trenched soil, 3.5-fold), and the average flux difference between the two treatments was 2.8 -fold. Isoprenoids, especially monoterpenes, were likely adsorbed on the leaf surfaces. Leaf surfaces are covered by a lipophilic cuticle layer that offers protection against environmental stress (cold, UV light, drought, etc.) (Pollard et al., 2008). Monoterpenes, as lipophilic and volatile compounds, can be absorbed on the lipophilic cuticle layer (Joensuu et al., 2016). Microbes living on plant surfaces can also modify VOC emissions by metabolizing plant-emitted VOCs (Farré-Armengol et al., 2016). The lowest isoprenoid fluxes were previously measured from soil with dense understorey vegetation cover (Aaltonen et al., 2013), which supports our conclusion.

The Vaccinium spp.-dominated understorey vegetation in Scots pine forests also synthesize monoterpenes (Faubert et al., 2012). Hanson et al. (1999) and Aaltonen et al. (2011) reported isoprenoid emissions from a forest floor covered with shrubs such as Vaccinium myrtillus, mosses such as Pleurozium schreberi and Hylocomium splendens, and grasses such as Melampyrum sylvaticum. Kesselmeier et al. (1999) reported that Pleurozium schreberi emits aldehydes. Temperate grassland species have been observed to emit isoprenoids (He et al., 2005), along with Mediterranean plant species (Owen et al., 2001), crop species, and tree species (Karl et al., 2009; Laothawornkitkul et al., 2009) such as Betula nana, Salix sp., Cassiope tetragona, and Populus tremula (Hakola et al., 1998; Rinnan et al., 2011). Hewitt and Street (1992) and Rinnan et al. (2013) discovered that Deschampsia sp. does not emit isoprene or monoterpenes. Subarctic heath emits isoprenoids (Faubert et al., 2012). Mosses are important to consider in the forest floor VOC exchange, as they emit isoprene (Hanson et al., 1999) and produce up to $40 \%$ of the gross photosynthetic production of the understorey vegetation at the SMEAR II stand (Kolari et al., 2006).

\subsection{Testing the factors involved in VOC flux from the forest floor}

This experimental setup was designed to determine whether carbon allocation to soil via the roots affects soil isoprenoid fluxes through root metabolism and microbial activity, and whether radiation-driven photosynthesized carbon availability for roots and microbes regulates isoprenoid fluxes. According to our statistical model, belowground carbon availability does not significantly affect the boreal forest soil isoprenoid exchange.

Our measurement setup enables us to test contributing factors for isoprenoid emissions by constructing a statistical model. Different statistical models were tested, but only the parameters with a statistically significant effect were included, and the best model with the highest explanatory power was chosen. The best model, which included seasonality, vegetation effect, prevailing temperature, and the interaction of these parameters, was able to explain $29-43 \%$ of the variation within monoterpene and sesquiterpene fluxes, which means that a significant portion of the variation was solved. We were also able to construct a model explaining $46 \%$ of the individual $\alpha$-pinene fluxes based on vegetation effect, seasonality, prevailing temperature, and the interaction of these parameters. This indicates that separate models should always be built for different compound groups (monoterpenes and sesquiterpenes) with different physical and chemical properties.

The mixed-effect linear models explained a considerable part $(43 \%)$ of the variation in monoterpene emissions, although more improvement should be achieved in the future. 
Possible reasons behind the emissions not explained by the model are oxygen and nutrient availability (Rinnan et al., 2011, the fertilization effect of Salix phylicifolia on the $\beta$ selinene flux), quality and quantity of the organic matter, soil composition, and microbial community structure, which were not determined in our study. It is also possible that some tested parameters were non-linear, and for this reason were unsuitable parameters for the mixed-effect linear model. A process-based model should be built in the future, as it would increase our understanding of the forest floor isoprenoid exchange by including dependencies of the different environmental parameters and soil processes.

\subsection{Error sources in the measurements}

Isoprenoids are difficult to measure under field conditions, as they are emitted in trace amounts and are highly reactive, which means that they can be removed through chemical reactions before they have been sampled or analyzed. Sesquiterpene emissions can be significantly higher than the currently measured flux rates since they are difficult to detect and quantify due to the low volatility and high reactivity (Guenther, 2013). Sesquiterpenes are important in the atmospheric processes since they have high precursor potential for SOA formation (Guenther et al., 2011). Sesquiterpene flux rates are probably underestimated more than isoprene and monoterpene flux rates, since daytime lifetime $(\mathrm{OH}$ and $\mathrm{O}_{3}$ ) in the atmosphere is $1.3 \mathrm{~min}$ for $\beta$-caryophyllene, $27 \mathrm{~min}$ for isoprene, $29 \mathrm{~min}$ for $\Delta^{3}$-carene, and $41 \mathrm{~min}$ for $\alpha$-pinene (Rinne et al., 2007), although the majority of oxidants are filtered before the chamber headspace. The difference in emission rates between treatments can be smaller than the random errors in the measured fluxes, produced by the sampling and analysis system. Total uncertainty for the emissions at the level $10 \mu \mathrm{g} \mathrm{m}^{-2} \mathrm{~h}^{-1}$, which was the median emission rate of $\alpha$-pinene, was $14-44 \%$ for monoterpenes (except for camphene: $60 \%$ ) and 14-20\% for sesquiterpenes (Appendix A, Table A2).

As the sampling time should to be considerably long (here: $1.5-2 \mathrm{~h}$ ) to exceed the detection limit of the TD-GC-MS, this means that the results are cumulative emissions over the sampling time. With fast-response analytical methods such as proton-transfer reaction mass spectrometry (PTR-MS), fast changes in the emissions could be followed. However, the speciation to different compounds is only possible with a TDGC-MS, which is why we chose to use this method.

Temperatures inside the enclosure typically increase during the measurements, especially if the enclosure time is long and the chamber is in direct sunlight. This can cause overestimations in the flux rates, when increasing temperature affects the volatility and diffusion rate of the compounds (Niinemets et al., 2011). Luckily, in our study, the median difference of enclosure temperature and ambient air was small $\left(0.9^{\circ} \mathrm{C}\right)$ for the entire data set, probably since we used a fan inside the chamber and the purge flow rate was approxi- mately $1 \mathrm{~L} \mathrm{~min}^{-1}$. Further, temperatures close to the soil surface are rather stable due to the lack of direct sunlight under the closed canopy.

Many isoprenoids are released in large amounts from cut surfaces or due to the rough handling of measured plants. The trenching and cutting of vegetation was performed 3 years prior to these measurements. Since the distance from our measurement collar to the closest trench was $30 \mathrm{~cm}$, we assume that the effect of root cutting is very small. Mechanical removal (cutting) of vegetation could cause some local effects and random variation to the plots where the vegetation was removed, but since the need for repeated cutting in the third year was rather small, and it was mostly performed in spring, we believe that it did not significantly affect the fluxes later on. Soil surfaces in the cut treatments were still partly covered by mosses (16-20\%), as it is impossible to remove a very thin moss cover without disturbing the organic soil. This may influence the observed differences between bare soil and soil with vegetation, as mosses are known to emit isoprene (Hanson et al., 1999). A minor trend was observed where the highest isoprene emissions occurred when the fraction of mosses made up over $55 \%$ of the soil surface coverage.

Soil is a highly heterogenic matrix, where soil depth, nutrient status, root density, and water content can vary based on vegetation cover, shading, and soil composition (porosity, texture, and stoniness). High spatial and temporal variation can make differences between the treatments more difficult to detect.

\section{Conclusions}

Our results show that belowground carbon availability does not play a major role in isoprenoid exchange, but instead the litterfall, i.e., carbon from above, is important. Our results emphasize that the net sink effect of understorey vegetation should be included for modeling forest VOC exchange. These results add to our knowledge concerning forest floor VOC fluxes for modeling stand-level VOC exchange. The accurate quantification of soil VOC fluxes can improve air chemistry models, where the difference in the hydroxyl radical $(\mathrm{OH})$ reactivity sink between the measurements and air chemistry models is most likely due to the unknown VOC sources (Mogensen et al., 2011). OH is the most important oxidant for atmospheric VOCs, and more accurate quantification of the $\mathrm{OH}$ reactivity sink is needed to enhance our understanding of the atmospheric capacity to oxidize gas-phase organic trace gases for SOA formation.

Data availability. Data are available and can be requested from the corresponding author (mari.maki@helsinki.fi). 


\section{Appendix A}

Total uncertainty of the emissions $\left(U_{\text {tot }}\right)$ was calculated directly from precision $\left(U_{\text {prec }}\right)$ and systematic errors $\left(U_{\text {sys }}\right)$ :

$U_{\text {tot }}^{2}=U_{\text {prec }}^{2}+U_{\text {sys }}^{2}$.

The precision $\left(U_{\text {prec }}\right)$ was calculated using Eq. (A2):

$U_{\text {prec }}=\frac{1}{3} \mathrm{DL}+\mathrm{RSD} \times \chi$,

where DL is the detection limit of the VOC quantification $\left(\mu \mathrm{g} \mathrm{m}^{-2} \mathrm{~h}^{-1}\right)$, RSD is relative standard deviation between the parallel samples taken from the chamber enclosures and $\chi$ is the median emission rate of $\alpha$-pinene: $10 \mu \mathrm{g} \mathrm{m}^{-2} \mathrm{~h}^{-1}$ ) at the SMEAR II site during periods 1 to 6, 2015 (Table A2). For lower emission rates uncertainties are expected to be higher.
The systematic error includes uncertainty of the standard preparation $\left(U_{\text {stdprep }}, 5 \%\right)$ estimated for the equipment that was used, uncertainty of the sample volume $\left(U_{\mathrm{vol}}, 3 \%\right)$ that was obtained for the uncertainty of the mass flow controllers, errors due to variation in ingoing air concentration $\left(U_{\text {in }}\right)$ was calculated using Eq. (A3) based on four replicates of the ingoing air and eight of the outgoing air during the chamber closure (Table A2).

$U_{\mathrm{sys}}^{2}=U_{\mathrm{stdprep}}^{2}+U_{\mathrm{vol}}^{2}+U_{\mathrm{in}}^{2}$

Systematic error was higher than error of the precision (see Table A2). This was mainly due to variations in ingoing air.

Recovery of different compounds was tested by injecting known amounts of studied compounds into ingoing air and recovery was measured from the outgoing air. Results are shown in Table A2.
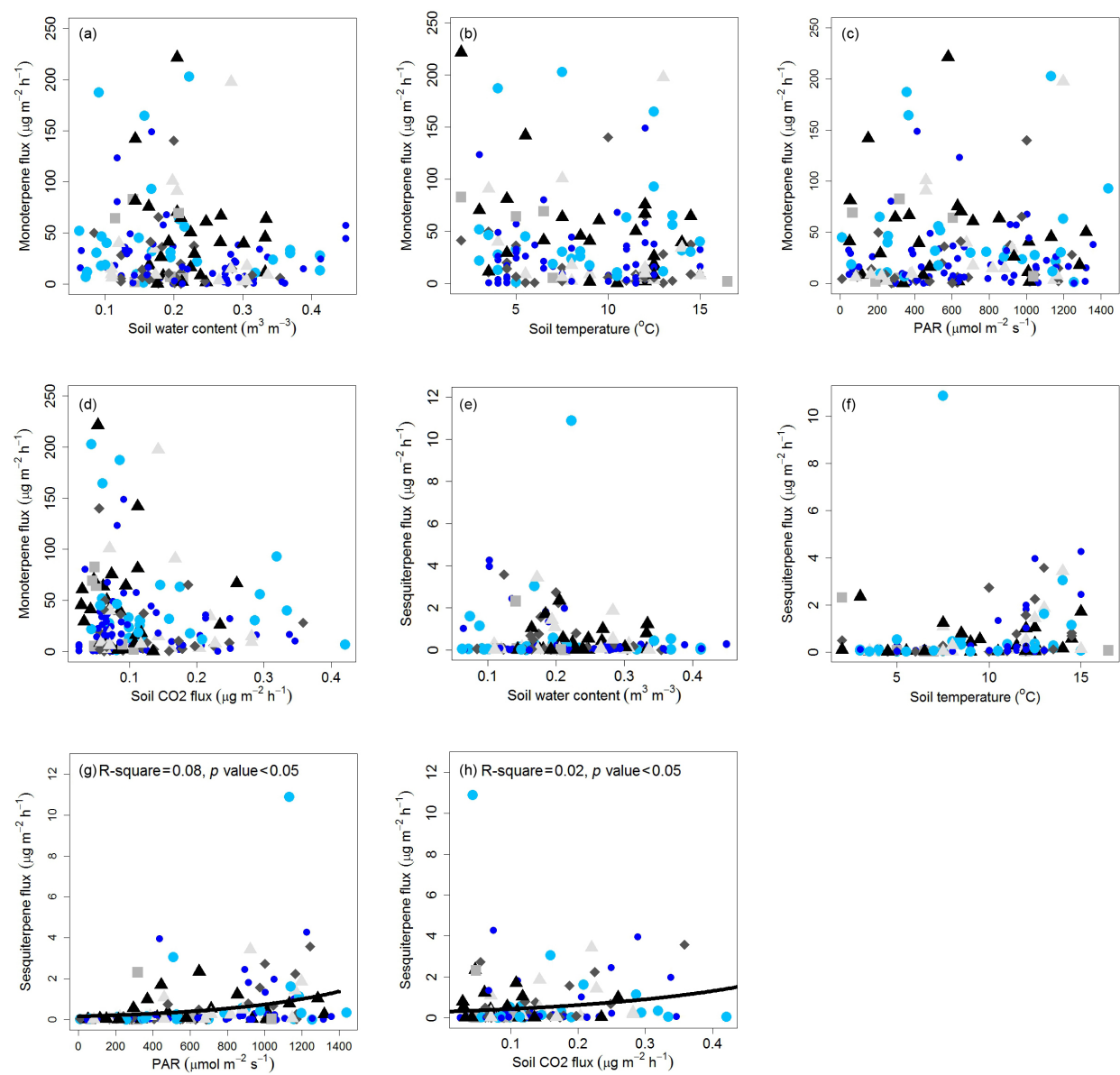

Figure A1. Relationships between monoterpene (a-d) and sesquiterpene flux (e-h) $\left(\mu \mathrm{g} \mathrm{m}^{-2} \mathrm{~h}^{-1}\right)$ and soil water content $\left(\mathrm{m}^{3} \mathrm{~m}^{-3}\right)$, soil temperature $\left({ }^{\circ} \mathrm{C}\right)$, above-canopy PAR $\left(\mu \mathrm{mol} \mathrm{m}{ }^{-2} \mathrm{~s}^{-1}\right)$, and soil $\mathrm{CO}_{2}$ flux $\left(\mu \mathrm{g} \mathrm{m}^{-2} \mathrm{~h}^{-1}\right)$. The presented data were combined from all treatments (Control: soil was non-trenched, Tr50: the ingrowth of mycorrhizal fungi was allowed, and $\operatorname{Tr} 1$ : decomposers were the only source) with vegetation $(+)$ and those with bare soil $(-)$. The treatments $($ Control $+=$ small blue circle, Control $-=$ solid blue circle, Tr50 $+=$ filled gray triangle point-up, $\operatorname{Tr} 50-=$ filled gray square, $\operatorname{Tr} 1+=$ filled gray diamond, and $\operatorname{Tr} 1-=$ filled black triangle point-up) were measured from April to October 2015. The regression coefficient and $p$ value are indicated where the regression was significant. 
Table A1. Chamber measurements from the different trenching treatments (Control+, Control-, $\operatorname{Tr} 1+$, $\operatorname{Tr} 1-$, $\operatorname{Tr} 50+$, $\operatorname{Tr} 50-)$ from 15 April to 23 October 2015.

\begin{tabular}{|c|c|c|c|c|c|c|c|c|}
\hline Time $(\mathrm{UTC}+2)$ & Trt & Plot & Time & Trt & Plot & Time & Trt & Plot \\
\hline 15 April 01:00 p.m. & $\operatorname{Tr} 1+$ & 2 & 23 May 04:00 p.m. & $\operatorname{Tr} 50+$ & 19 & 31 August 01:00 p.m. & Control+ & 37 \\
\hline 15 April 03:00 p.m. & $\operatorname{Tr} 1+$ & 1 & 22 June 10:00 a.m. & Control- & 52 & 31 August 04:00 p.m. & Control- & 43 \\
\hline 16 April 10:00 a.m. & Control+ & 38 & 22 June 10:00 a.m. & $\operatorname{Tr} 1+$ & 14 & 1 September 08:00 a.m. & Control+ & 39 \\
\hline 16 April 01:00 p.m. & Control+ & 38 & 22 June 12:00 a.m. & $\operatorname{Tr} 1-$ & 18 & 1 September 11:00 a.m. & $\operatorname{Tr} 50-$ & 11 \\
\hline 17 April 09:00 a.m. & Control+ & 38 & 22 June 01:00 p.m. & Control+ & 46 & 1 September 01:00 p.m. & Control+ & 38 \\
\hline 17 April 01:00 p.m. & Control+ & 38 & 22 June 03:00 p.m. & Control+ & 48 & 1 September 04:00 p.m. & $\operatorname{Tr} 50+$ & 7 \\
\hline 23 April 10:00 a.m. & Control+ & 53 & 22 June 03:00 p.m. & $\operatorname{Tr} 50+$ & 19 & 2 September 09:00 a.m. & Control- & 44 \\
\hline 23 April 12:00 p.m. & Control+ & 53 & 23 June 09:00 a.m. & Control+ & 53 & 2 September 11:00 a.m. & Control+ & 40 \\
\hline 23 April 02:00 p.m. & Control+ & 53 & 23 June 10:00 a.m. & $\operatorname{Tr} 1-$ & 29 & 2 September 02:00 p.m. & $\operatorname{Tr} 1+$ & 2 \\
\hline 24 April 03:00 p.m. & Control+ & 37 & 23 June $12: 00$ p.m. & Control- & 59 & 2 September 04:00 p.m. & $\operatorname{Tr} 1-$ & 6 \\
\hline 25 April 09:00 a.m. & Control+ & 56 & 23 June $12: 00$ p.m. & $\operatorname{Tr} 50+$ & 31 & 3 September 09:00 a.m. & $\operatorname{Tr} 1-$ & 17 \\
\hline 25 April 10:00 a.m. & Control- & 51 & 23 June 03:00 p.m. & Control+ & 55 & 3 September 11:00 a.m. & Control- & 51 \\
\hline 25 April 12:00 p.m. & Control+ & 48 & 23 June 03:00 p.m. & $\operatorname{Tr} 1+$ & 25 & 3 September 01:00 p.m. & Control+ & 45 \\
\hline 25 April 01:00 p.m. & Control- & 52 & 24 June 08:00 a.m. & Control- & 60 & 3 September 04:00 p.m. & $\operatorname{Tr} 1+$ & 13 \\
\hline 30 April 09:00 a.m. & $\operatorname{Tr} 1+$ & 1 & 24 June 08:00 a.m. & Control+ & 54 & 4 September 09:00 a.m. & Control+ & 47 \\
\hline 30 April 09:00 a.m. & $\operatorname{Tr} 1-$ & 5 & 24 June 11:00 a.m. & $\operatorname{Tr} 1-$ & 30 & 4 September 11:00 a.m. & Control+ & 47 \\
\hline 30 April 11:00 a.m. & Control+ & 39 & 24 June 11:00 a.m. & $\operatorname{Tr} 1+$ & 26 & 4 September 01:00 p.m. & $\operatorname{Tr} 50+$ & 19 \\
\hline 30 April 02:00 p.m. & Control+ & 37 & 24 June 01:00 p.m. & Control+ & 56 & 4 September 03:00 p.m. & $\operatorname{Tr} 50+$ & 19 \\
\hline 30 April 03:00 p.m. & $\operatorname{Tr} 50+$ & 7 & 24 June $02: 00$ p.m. & $\operatorname{Tr} 50+$ & 31 & 5 October 08:00 a.m. & Control+ & 48 \\
\hline 2 May 09:00 a.m. & Control- & 44 & 21 July 09:00 a.m. & Control+ & 39 & 5 October 10:00 a.m. & $\operatorname{Tr} 1-$ & 18 \\
\hline 2 May 11:00 a.m. & $\operatorname{Tr} 1+$ & 2 & 21 July $12: 00$ p.m. & Control- & 43 & 5 October 12:00 p.m. & Control+ & 46 \\
\hline 2 May 02:00 p.m. & Control+ & 40 & 21 July $02: 00$ p.m. & $\operatorname{Tr} 1+$ & 1 & 5 October 02:00 p.m. & Control- & 52 \\
\hline 2 May 02:00 p.m. & Control+ & 38 & 21 July 05:00 p.m. & $\operatorname{Tr} 1-$ & 5 & 6 October 08:00 a.m. & $\operatorname{Tr} 1+$ & 14 \\
\hline 3 May 09:00 a.m. & Control+ & 47 & 21 July 09:00 a.m. & Control+ & 37 & 6 October 10:00 a.m. & $\operatorname{Tr} 50+$ & 19 \\
\hline 3 May 09:00 a.m. & Control- & 51 & 22 July $12: 00$ p.m. & $\operatorname{Tr} 1+$ & 2 & 6 October 12:00 p.m. & $\operatorname{Tr} 50-$ & 23 \\
\hline 3 May 12:00 p.m. & Control+ & 45 & 22 July $02: 00$ p.m. & $\operatorname{Tr} 1-$ & 6 & 6 October $02: 00$ p.m. & Control+ & 53 \\
\hline 3 May 12:00 p.m. & $\operatorname{Tr} 1+$ & 13 & 22 July 05:00 p.m. & Control- & 44 & 6 October 04:00 p.m. & Control+ & 55 \\
\hline 8 May 09:00 a.m. & $\operatorname{Tr} 1-$ & 18 & 23 July 08:00 a.m. & Control+ & 38 & 7 October 08:00 a.m. & Control+ & 56 \\
\hline 8 May 09:00 a.m. & Control+ & 48 & 23 July 11:00 a.m. & Control+ & 40 & 7 October 10:00 a.m. & $\operatorname{Tr} 1+$ & 25 \\
\hline 8 May $12: 00$ p.m. & Control- & 52 & 23 July 01:00 p.m. & Control- & 51 & 7 October 12:00 p.m. & $\operatorname{Tr} 1-$ & 29 \\
\hline 8 May $12: 00$ p.m. & $\operatorname{Tr} 1+$ & 14 & 23 July 04:00 p.m. & $\operatorname{Tr} 1-$ & 17 & 7 October 02:00 p.m. & Control- & 59 \\
\hline 8 May 02:00 p.m. & $\operatorname{Tr} 50+$ & 19 & 23 July $06: 00$ p.m. & $\operatorname{Tr} 1+$ & 13 & 8 October 08:00 a.m. & Control- & 60 \\
\hline 9 May 12:00 p.m. & Control+ & 53 & 24 July $06: 00$ a.m. & Control+ & 47 & 8 October 10:00 a.m. & Control+ & 54 \\
\hline 9 May 12:00 p.m. & $\operatorname{Tr} 1+$ & 26 & 24 July 09:00 a.m. & Control+ & 45 & 8 October 12:00 p.m. & $\operatorname{Tr} 1-$ & 30 \\
\hline 10 May 08:00 a.m. & Control- & 60 & 24 July 11:00 a.m. & $\operatorname{Tr} 50+$ & 19 & 8 October 03:00 p.m. & $\operatorname{Tr} 1+$ & 26 \\
\hline 10 May 11:00 a.m. & Control+ & 56 & 17 August 10:00 a.m. & $\operatorname{Tr} 1-$ & 18 & 9 October 08:00 a.m. & $\operatorname{Tr} 50-$ & 35 \\
\hline 10 May 11:00 a.m. & $\operatorname{Tr} 1-$ & 30 & 17 August $12: 00$ p.m. & Control+ & 48 & 9 October 09:00 a.m. & $\operatorname{Tr} 50+$ & 31 \\
\hline 10 May 01:00 p.m. & $\operatorname{Tr} 50-$ & 35 & 17 August $03: 00$ p.m. & Control- & 52 & 19 October 07:00 p.m. & Control- & 43 \\
\hline 10 May 02:00 p.m. & $\operatorname{Tr} 50+$ & 31 & 18 August 09:00 a.m. & $\operatorname{Tr} 1+$ & 14 & 19 October 12:00 p.m. & $\operatorname{Tr} 1+$ & 1 \\
\hline 21 May 10:00 a.m. & Control- & 43 & 18 August 11:00 a.m. & Control+ & 46 & 19 October 02:00 p.m. & Control+ & 39 \\
\hline 21 May 10:00 a.m. & Control+ & 37 & 18 August $02: 00$ p.m. & $\operatorname{Tr} 50+$ & 19 & 20 October 08:00 a.m. & Control+ & 37 \\
\hline 21 May 01:00 p.m. & $\operatorname{Tr} 1-$ & 5 & 18 August 05:00 p.m. & $\operatorname{Tr} 50-$ & 23 & 20 October 10:00 a.m. & $\operatorname{Tr} 50+$ & 7 \\
\hline 21 May 01:00 p.m. & Control- & 43 & 19 August 09:00 a.m. & Control+ & 55 & 20 October 01:00 p.m. & $\operatorname{Tr} 1-$ & 5 \\
\hline 21 May 04:00 p.m. & Control+ & 39 & 19 August 11:00 a.m. & Control- & 59 & 20 October 03:00 p.m. & $\operatorname{Tr} 50-$ & 11 \\
\hline 22 May 09:00 a.m. & Control+ & 40 & 19 August $02: 00$ p.m. & $\operatorname{Tr} 1+$ & 25 & 21 October 08:00 a.m. & $\operatorname{Tr} 1+$ & 2 \\
\hline 22 May 09:00 a.m. & $\operatorname{Tr} 1+$ & 2 & 19 August 04:00 p.m. & $\operatorname{Tr} 1-$ & 29 & 21 October 10:00 a.m. & Tr1- & 6 \\
\hline 22 May 11:00 a.m. & $\mathrm{Tr}-$ & 6 & 20 August 09:00 a.m. & $\operatorname{Tr} 50+$ & 31 & 21 October 12:00 p.m. & $\operatorname{Tr} 1-$ & 5 \\
\hline 22 May 12:00 p.m. & Control- & 44 & 20 August 12:00 a.m. & Control+ & 53 & 21 October 01:00 p.m. & Control+ & 38 \\
\hline 22 May 02:00 p.m. & Control+ & 38 & 20 August 02:00 p.m. & Control+ & 56 & 21 October 03:00 p.m. & Control- & 44 \\
\hline 22 May 02:00 p.m. & $\operatorname{Tr} 1+$ & 1 & 21 August 09:00 a.m. & Control- & 60 & 22 October 08:00 a.m. & $\operatorname{Tr} 1-$ & 17 \\
\hline 23 May 10:00 a.m. & $\operatorname{Tr} 1+$ & 13 & 21 August 11:00 a.m. & $\operatorname{Tr} 1+$ & 26 & 22 October 10:00 a.m. & Control+ & 45 \\
\hline 23 May 01:00 p.m. & Control+ & 45 & 21 August 04:00 p.m. & Control+ & 54 & 22 October 12:00 p.m. & Control- & 51 \\
\hline 23 May 01:00 p.m. & Control- & 51 & 31 August 08:00 a.m. & $\operatorname{Tr} 1+$ & 1 & 22 October 03:00 p.m. & $\operatorname{Tr} 1+$ & 13 \\
\hline 23 May 03:00 p.m. & $\operatorname{Tr} 1-$ & 17 & 31 August 10:00 a.m. & $\operatorname{Tr} 1-$ & 5 & 23 October 08:00 a.m. & Control+ & 47 \\
\hline & & & & & & 23 October 10:00 a.m. & $\operatorname{Tr} 50+$ & 19 \\
\hline
\end{tabular}


Table A2. Relative standard deviation between the parallel samples taken from the chamber enclosures (RSD, \%), the detection limit of the VOC quantification (DL, $\mu \mathrm{g} \mathrm{m}^{-2} \mathrm{~h}^{-1}$ ), and errors due to variation in ingoing air concentration $\left(U_{\text {in }}\right.$, \%), and based on these values, precision $\left(U_{\text {prec }}, \%\right)$, systematic error $\left(U_{\text {sys }}, \%\right)$, and total uncertainty $\left(U_{\text {tot }}, \%\right)$ of the emissions were calculated for the emissions at the level $10 \mu \mathrm{g} \mathrm{m}^{-2} \mathrm{~h}^{-1}$, which was mean emission rate of $\alpha$-pinene.

\begin{tabular}{lrrrrrr}
\hline & RSD & DL & $U_{\text {in }}$ & $U_{\text {prec }}$ & $U_{\text {sys }}$ & $U_{\text {tot }}$ \\
\hline Monoterpenes & & & & & & \\
\hline$\alpha$-pinene & $8 \%$ & 0.84 & $32 \%$ & $11 \%$ & $33 \%$ & $35 \%$ \\
camphene & $8 \%$ & 0.18 & $59 \%$ & $8 \%$ & $29 \%$ & $60 \%$ \\
$\beta$-pinene & $7 \%$ & 0.01 & $17 \%$ & $7 \%$ & $27 \%$ & $20 \%$ \\
myrcene & $7 \%$ & 0.01 & $10 \%$ & $7 \%$ & $27 \%$ & $14 \%$ \\
$\Delta 3$-carene & $10 \%$ & 0.53 & $42 \%$ & $12 \%$ & $34 \%$ & $44 \%$ \\
p-cymene & $11 \%$ & 0.04 & $26 \%$ & $11 \%$ & $33 \%$ & $29 \%$ \\
limonene & $11 \%$ & 0.08 & $17 \%$ & $11 \%$ & $34 \%$ & $22 \%$ \\
terpinolene & $12 \%$ & 0.002 & $7 \%$ & $12 \%$ & $34 \%$ & $15 \%$ \\
\hline Sesquiterpenes & & & & & & \\
\hline longicyclene & $10 \%$ & 0.004 & $8 \%$ & $10 \%$ & $32 \%$ & $14 \%$ \\
$\beta$-caryophyllene & $12 \%$ & 0.022 & $15 \%$ & $12 \%$ & $34 \%$ & $20 \%$ \\
$\alpha$-humulene & $10 \%$ & 0.004 & $15 \%$ & $10 \%$ & $32 \%$ & $19 \%$ \\
\hline
\end{tabular}
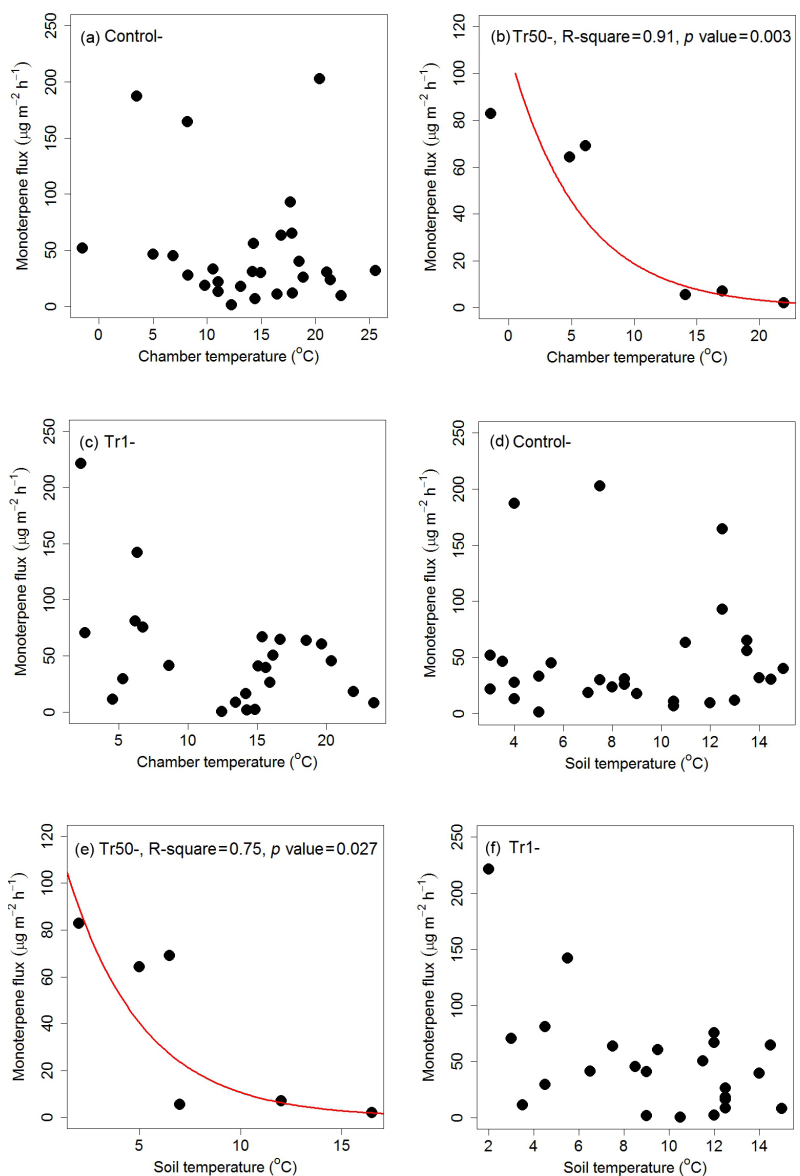

Figure A2. Relationships between monoterpene flux $\left(\mu \mathrm{g} \mathrm{m}^{-2} \mathrm{~h}^{-1}\right)$ and chamber temperature $\left({ }^{\circ} \mathrm{C}\right)$ on Control- (bare soil was non-trenched), $\operatorname{Tr} 50$ - (bare soil where ingrowth of mycorrhizal fungi was allowed), and $\operatorname{Tr} 1$ - (bare soil where decomposers were the only source) plots (a, b, c) and soil temperature $\left({ }^{\circ} \mathrm{C}\right)$ on Control-, Tr50-, and $\operatorname{Tr} 1-$ plots $(\mathbf{d}, \mathbf{e}, \mathbf{f})$. The presented data were combined from all the periods in 2015. The regression coefficient and $p$ value are indicated where the regression was significant. 
Author contributions. Manuscript preparation and analysis of results was carried out by Mari Mäki. All authors contributed to project planning, experimental design, the discussion of the results, and commenting on the manuscript.

Competing interests. The authors declare that they have no conflict of interest.

Acknowledgements. This research was founded by the Academy of Finland Center of Excellence programme (grant no. 272041) and by the Jenny and Antti Wihuri Foundation. The research was also supported by the Academy research fellow projects (Academy of Finland, projects 275608, 263858, and 292699). We also thank Eeva-Stiina Tuittila and Aino Korrensalo for the understorey vegetation survey on the experimental plots, Jarkko Isotalo for the guidance on the statistical analysis, and the staff of the SMEAR II station and Hyytiälä Forestry Field station.

Edited by: M. Glasius

Reviewed by: A. B. Guenther and two anonymous referees

\section{References}

Aalto, J., Kolari, P., Hari, P., Kerminen, V.-M., Schiestl-Aalto, P., Aaltonen, H., Levula, J., Siivola, E., Kulmala, M., and Bäck, J.: New foliage growth is a significant, unaccounted source for volatiles in boreal evergreen forests, Biogeosciences, 11, 13311344, doi:10.5194/bg-11-1331-2014, 2014.

Aaltonen, H., Pumpanen, J., Pihlatie, M., Hakola, H., Hellén, H., Kulmala, L., Vesala, T., and Bäck, J.: Boreal pine forest floor biogenic volatile organic compound fluxes peak in early summer and autumn, Agr. Forest Meteorol., 151, 682-691, doi:10.1016/j.agrformet.2010.12.010, 2011.

Aaltonen, H., Pumpanen, J., Hakola, H., Vesala, T., Rasmus, S., and Bäck, J.: Snowpack concentrations and estimated fluxes of volatile organic compounds in a boreal forest, Biogeosciences, 9, 2033-2044, doi:10.5194/bg-9-2033-2012, 2012.

Aaltonen, H., Aalto, J., Kolari, P., Pihlatie, M., Pumpanen, J., Kulmala, M., Nikinmaa, E., Vesala, T., and Bäck, J.: Continuous VOC flux measurements on boreal forest floor, Plant and Soil, 369, 241-256, doi:10.1007/s11104-012-1553-4, 2013.

Adamczyk, S., Adamczyk, B., Kitunen, V., and Smolander, A.: Monoterpenes and higher terpenes may inhibit enzyme activities in boreal forest soil, Soil Biol. Biochem., 87, 59-66, doi:10.1016/j.soilbio.2015.04.006, 2015.

Asensio, D., Peñuelas, J., Filella, I., and Llusià, J.: On-line screening of soil VOCs exchange responses to moisture, temperature and root presence, Plant Soil, 291, 249-261, doi:10.1007/s11104-006-9190-4, 2007.

Asensio, D., Peñuelas, J., Prieto, P., Estiarte, M., Filella, I., and Llusià, J.: Interannual and seasonal changes in the soil exchange rates of monoterpenes and other VOCs in a Mediterranean shrubland, Eur. J. Soil Sci., 59, 878-891, doi:10.1111/j.13652389.2008.01057.x, 2008.

Asensio, D., Yuste, J. C., Mattana, S., Ribas, À., Llusià, J., and Peñuelas, J.: Litter VOCs induce changes in soil microbial biomass $\mathrm{C}$ and $\mathrm{N}$ and largely increase soil $\mathrm{CO}_{2}$ efflux, Plant Soil, 360, 163-174, doi:10.1007/s11104-012-1220-9, 2012.

Bäck, J., Aaltonen, H., Hellén, H., Kajos, M. K., Patokoski, J., Taipale, R., Pumpanen, J., and Heinonsalo, J.: Variable fluxes of microbial volatile organic compounds (MVOCs) from rootassociated fungi isolated from Scots pine, Atmos. Environ., 44, 3651-3659, doi:10.1016/j.atmosenv.2010.06.042, 2010.

Bäck, J., Aalto, J., Henriksson, M., Hakola, H., He, Q., and Boy, M.: Chemodiversity of a Scots pine stand and implications for terpene air concentrations, Biogeosciences, 9, 689-702, doi:10.5194/bg-9-689-2012, 2012.

Banerjee, A. and Sharkey, T. D.: Methylerythritol 4-phosphate (MEP) pathway metabolic regulation, Nat. Prod. Rep., 31, 1043 1055, doi:10.1039/C3NP70124G, 2014.

Bouvier-Brown, N. C., Goldstein, A. H., Gilman, J. B., Kuster, W. C., and de Gouw, J. A.: In-situ ambient quantification of monoterpenes, sesquiterpenes, and related oxygenated compounds during BEARPEX 2007: implications for gas- and particle-phase chemistry, Atmos. Chem. Phys., 9, 5505-5518, doi:10.5194/acp-9-5505-2009, 2009.

Chatani, S., Matsunaga, S. N., and Nakatsuka, S.: Estimate of biogenic VOC emissions in Japan and their effects on photochemical formation of ambient ozone and secondary organic aerosol, Atmos. Environ., 120, 38-50, doi:10.1016/j.atmosenv.2015.08.086, 2015.

Ditengou, F. A., Müller, A., Rosenkranz, M., Felten, J., Lasok, H., van Doorn, M. M., Legue, V., Palme, K., Schnitzler, J.-P., and Polle, A.: Volatile signalling by sesquiterpenes from ectomycorrhizal fungi reprogrammes root architecture, Nat. Commun., 6, 6279, doi:10.1038/ncomms7279, 2015.

Eisenreich, W., Schwarz, M., Cartayrade, A., Arigoni, D., Zenk, M. H., and Bacher, A.: The deoxyxylulose phosphate pathway of terpenoid biosynthesis in plants and microorganisms, Chem. Biol., 5, R221-R233, 1998.

Faiola, C. L., VanderSchelden, G. S., Wen, M., Elloy, F. C., Cobos, D. R., Watts, R. J., Jobson, B. T., and VanReken, T. M.: SOA Formation Potential of Fluxes from Soil and Leaf Litter, Environ. Sci. Technol., 48, 938-946, doi:10.1021/es4040045, 2014.

Farré-Armengol, G., Filella, I., Llusia, J., and Peñuelas, J.: Bidirectional Interaction between Phyllospheric Microbiotas and Plant Volatile Emissions, Trends Plant Sci., 21, 854-860, 2016.

Faubert, P., Tiiva, P., Michelsen, A., Rinnan, Å., Ro-Poulsen, H., and Rinnan, R.: The shift in plant species composition in a subarctic mountain birch forest floor due to climate change would modify the biogenic volatile organic compound emission profile, Plant Soil, 352, 199-215, doi:10.1007/s11104-011-0989-2, 2012.

Fogel, R. and Hunt, G.: Contribution of mycorrhizae and soil fungi to nutrient cycling in a Douglas-fir ecosystem, Can. J. Forest Res., 13, 219-232, 1983.

Ghirardo, A., Gutknecht, J., Zimmer, I., Brüggemann, N., and Schnitzler, J. P.: Biogenic volatile organic compound and respiratory $\mathrm{CO}_{2}$ fluxes after ${ }^{13} \mathrm{C}$-labeling: online tracing of $\mathrm{C}$ translocation dynamics in poplar plants, PLoS One, 6, e17393, doi:10.1371/journal.pone.0017393, 2011.

Grayston, S. J., Vaughan, D., and Jones, D.: Rhizosphere carbon flow in trees, in comparison with annual plants: the importance of root exudation and its impact on microbial activity and nutri- 
ent availability, Appl. Soil Ecol., 5, 29-56, doi:10.1016/S09291393(96)00126-6, 1997.

Greenberg, J. P., Asensio, D., Turnipseed, A., Guenther, A. B., Karl, T., and Gochis, D.: Contribution of leaf and needle litter to whole ecosystem BVOC fluxes, Atmos. Environ., 59, 302-311, doi:10.1016/j.atmosenv.2012.04.038, 2012.

Grote, R. and Niinemets, Ü.: Modeling volatile isoprenoid emissions - a story with split ends, Plant Biol., 10, 8-28, doi:10.1055/s-2007-964975, 2008.

Guenther, A.: Biological and chemical diversity of biogenic volatile organic fluxes into the atmosphere, ISRN Atmospheric Sciences, Vol. 2013, doi:10.1155/2013/786290, 2013.

Guenther, A., Hewitt, C. N., Erickson, D., Fall, R., Geron, C., Graedel, T., Harley P., Klinger L., Lerdau, M., Mckay, W. A., Pierce, T., Scholes, B., Steinbrecher, R., Tallamraju, R., Taylor, J., and Zinnerman, P.: A global model of natural volatile organic compound emissions, J. Geophys. Res.-Atmos., 100, 8873-8892, doi:10.1029/94JD02950, 1995.

Guenther, A., Karl, T., Harley, P., Wiedinmyer, C., Palmer, P. I., and Geron, C.: Estimates of global terrestrial isoprene emissions using MEGAN (Model of Emissions of Gases and Aerosols from Nature), Atmos. Chem. Phys., 6, 3181-3210, doi:10.5194/acp-63181-2006, 2006.

Guenther, A., Kulmala, M., Turnipseed, A., Rinne, J., Suni, T., and Reissell, A.: Integrated land ecosystem-atmosphere processes study (iLEAPS) assessment of global observational networks, Boreal Environ. Res., 16, 321-336, 2011.

Guenther, A. B., Monson, R. K., and Fall, R.: Isoprene and monoterpene emission rate variability: observations with eucalyptus and emission rate algorithm development, J. Geophys. Res.-Atmos., 96, 10799-10808, doi:10.1029/91JD00960, 1991.

Guenther, A. B., Zimmerman, P. R., Harley, P. C., Monson, R. K., and Fall, R.: Isoprene and monoterpene emission rate variability: model evaluations and sensitivity analyses, J. Geophys. Res.Atmos., 98, 12609-12617, doi:10.1029/93JD00527, 1993.

Guenther, A. B., Jiang, X., Heald, C. L., Sakulyanontvittaya, T., Duhl, T., Emmons, L. K., and Wang, X.: The Model of Emissions of Gases and Aerosols from Nature version 2.1 (MEGAN2.1): an extended and updated framework for modeling biogenic emissions, Geosci. Model Dev., 5, 1471-1492, doi:10.5194/gmd-51471-2012, 2012.

Haapanala, S., Hakola, H., Hellén, H., Vestenius, M., Levula, J., and Rinne, J.: Is forest management a significant source of monoterpenes into the boreal atmosphere?, Biogeosciences, 9, 12911300, doi:10.5194/bg-9-1291-2012, 2012.

Hakola, H., Rinne, J., and Laurila, T.: The hydrocarbon emission rates of tea-leafed willow (Salix phylicifolia), silver birth (Betula pendula) and European aspen (Populus tremula), Atmos. Environ., 32, 1825-1833, doi:10.1016/S1352-2310(97)00482-2, 1998.

Hakola, H., Tarvainen, V., Laurila, T., Hiltunen, V., Hellén, H., and Keronen, P.: Seasonal variation of VOC concentrations above a boreal coniferous forest, Atmos. Environ., 37, 1623-1634, doi:10.1016/S1352-2310(03)00014-1, 2003.

Hanson, D. T., Swanson, S., Graham, L. E., and Sharkey, T. D.: Evolutionary significance of isoprene emission from mosses, Am. J. Bot., 86, 634-639, 1999.
Hari, P. and Kulmala, M.: Station for Measuring EcosystemAtmosphere Relations (SMEAR II), Boreal Environ. Res., 10, 315-322, 2005.

Hayward, S., Muncey, R. J., James, A. E., Halsall, C. J., and Hewitt, C. N.: Monoterpene fluxes from soil in a Sitka spruce forest, Atmos. Environ., 35, 4081-4087, doi:10.1016/S13522310(01)00213-8, 2001.

He, N. P., Han, X. G., and Pan, Q. M.: Variations in the volatile organic compound emission potential of plant functional groups in the temperate grassland vegetation of inner Mongolia, China, J. Integr. Plant Biol., 47, 13-19, 2005.

Hellén, H., Hakola, H., Pystynen, K.-H., Rinne, J., and Haapanala, S.: $\mathrm{C}_{2}-\mathrm{C}_{10}$ hydrocarbon emissions from a boreal wetland and forest floor, Biogeosciences, 3, 167-174, doi:10.5194/bg-3-1672006, 2006.

Hewitt, C. N. and Street, R. A.: A qualitative assessment of the emission of non-methane hydrocarbon compounds from the biosphere to the atmosphere in the UK: present knowledge and uncertainties, Atmos. Environ. A-Gen., 26, 3069-3077, doi:10.1016/0960-1686(92)90463-U, 1992.

Högberg, P., Nordgren, A., Buchmann, N., Taylor, A. F., Ekblad, A., Högberg, M. N., Nyberg, G., Ottosson-Löfvenius, M., and Read, D. J.: Large-scale forest girdling shows that current photosynthesis drives soil respiration, Nature, 411, 789-792, doi:10.1038/35081058, 2001.

Högberg, M. N., Briones, M. J., Keel, S. G., Metcalfe, D. B., Campbell, C., Midwood, A. J., Thornton, V. H., Linder, S., Näsholm, T., and Högberg, P.: Quantification of effects of season and nitrogen supply on tree below-ground carbon transfer to ectomycorrhizal fungi and other soil organisms in a boreal pine forest, New Phytol., 187, 485-493, doi:10.1111/J.1469-8137.2010.03274.X, 2010.

Hung, R., Lee, S., and Bennett, J. W.: Arabidopsis thaliana as a model system for testing the effect of Trichoderma volatile organic compounds, Fungal Ecol., 6, 19-26, doi:10.1016/j.funeco.2012.09.005, 2013.

Ilvesniemi, H., Levula, J., Ojansuu, R., Kolari, P., Kulmala, L., Pumpanen, J., Launiainen, S., Vesala, T., and Nikinmaa, E.: Long-term measurements of the carbon balance of a boreal Scots pine dominated forest ecosystem, Boreal Environ. Res., 14, 731753, 2009.

Insam, H. and Seewald, M. S.: Volatile organic compounds (VOCs) in soils, Biol. Fert. Soils, 46, 199-213, doi:10.1007/s00374-0100442-3, 2010.

Isidorov, V. A., Smolewska, M., Purzynska-Pugacewicz, A., and Tyszkiewicz, Z.: Chemical composition of volatile and extractive compounds of pine and spruce leaf litter in the initial stages of decomposition, Biogeosciences, 7, 2785-2794, doi:10.5194/bg7-2785-2010, 2010.

Joensuu, J., Altimir, N., Hakola, H., Rostás, M., Raivonen, M., Vestenius, M., Aaltonen, H., Riederer, M., and Bäck, J.: Role of needle surface waxes in dynamic exchange of mono- and sesquiterpenes, Atmos. Chem. Phys., 16, 7813-7823, doi:10.5194/acp-16-7813-2016, 2016.

Johnson, P. C.: Extension of Nakagawa \& Schielzeth's R2GLMM to random slopes models, Methods in Ecology and Evolution, 5, 944-946, doi:10.1111/2041-210X.12225, 2014.

Kai, M., Effmert, U., Berg, G., and Piechulla, B.: Volatiles of bacterial antagonists inhibit mycelial growth of the plant 
pathogen Rhizotonia solani, Arch. Microbiol., 187, 351-360, doi:10.1007/s00203-006-0199-0, 2007.

Kainulainen, P. and Holopainen, J. K.: Concentrations of secondary compounds in Scots pine needles at different stages of decomposition, Soil Biol. Biochem., 34, 37-42, doi:10.1016/S00380717(01)00147-X, 2002.

Karl, M., Guenther, A., Köble, R., Leip, A., and Seufert, G.: A new European plant-specific emission inventory of biogenic volatile organic compounds for use in atmospheric transport models, Biogeosciences, 6, 1059-1087, doi:10.5194/bg-6-1059-2009, 2009.

Kesselmeier, J., Wilske, B., Muth, S., Bode, K., and Wolf, A.: Exchange of oxygenated volatile organic compounds between boreal lichens and the atmosphere. LAURILA T, LINDFORS V. Biogenic VOC emissions and photochemistry in the boreal regions of Europe, CEC Air Pollution Research Report. Luxembourg: Official Publication of the European Commission, 70, 5771, 1999.

Kim, J. C., Kim, K. J., Kim, D. S., and Han, J. S.: Seasonal variations of monoterpene fluxes from coniferous trees of different ages in Korea, Chemosphere, 59, 1685-1696, doi:10.1016/j.chemosphere.2004.10.048, 2005.

Kolari, P., Pumpanen, J., Kulmala, L., Ilvesniemi, H., Nikinmaa, E., Grönholm, T., and Hari, P.: Forest floor vegetation plays an important role in photosynthetic production of boreal forests, Forest Ecol. Manage., 221, 241-248, doi:10.1016/j.foreco.2005.10.021, 2006.

Laothawornkitkul, J., Taylor, J. E., Paul, N. D., and Hewitt, C. N.: Biogenic volatile organic compounds in the Earth system, New Phytol., 183, 27-51, doi:10.1111/j.1469-8137.2009.02859.x, 2009.

Leff, J. W. and Fierer, N.: Volatile organic compound (VOC) emissions from soil and litter samples, Soil Biol. Biochem., 40, 16291636, doi:10.1016/j.soilbio.2008.01.018, 2008.

Lin, C., Owen, S. M., and Peñuelas, J.: Volatile organic compounds in the roots and rhizosphere of Pinus spp., Soil Biol. Biochem., 39, 951-960, doi:10.1016/j.soilbio.2006.11.007, 2007.

Mackie, A. E. and Wheatley, R. E.: Effects and incidence of volatile organic compound interactions between soil bacterial and fungal isolates, Soil Biol. Biochem., 31, 375-385, doi:10.1016/S00380717(98)00140-0, 1999.

Mancuso, S., Taiti, C., Bazihizina, N., Costa, C., Menesatti, P., Giagnoni, L., Arenella, M., Nannipieri P., and Renella, G.: Soil volatile analysis by proton transfer reaction-time of flight mass spectrometry (PTR-TOF-MS), Appl. Soil Ecol., 86, 182-191, doi:10.1016/j.apsoil.2014.10.018, 2015.

Mogensen, D., Smolander, S., Sogachev, A., Zhou, L., Sinha, V., Guenther, A., Williams, J., Nieminen, T., Kajos, M. K., Rinne, J., Kulmala, M., and Boy, M.: Modelling atmospheric $\mathrm{OH}$-reactivity in a boreal forest ecosystem, Atmos. Chem. Phys., 11, 97099719, doi:10.5194/acp-11-9709-2011, 2011.

Nakagawa, S. and Schielzeth, H.: A general and simple method for obtaining $R^{2}$ from generalized linear mixed-effects models, Methods in Ecology and Evolution, 4, 133-142, doi:10.1111/j.2041-210x.2012.00261.x, 2013.

Niinemets, Ü., Kuhn, U., Harley, P. C., Staudt, M., Arneth, A., Cescatti, A., Ciccioli, P., Copolovici, L., Geron, C., Guenther, A., Kesselmeier, J., Lerdau, M. T., Monson, R. K., and Peñuelas, J.: Estimations of isoprenoid emission capacity from enclosure studies: measurements, data processing, quality and stan- dardized measurement protocols, Biogeosciences, 8, 2209-2246, doi:10.5194/bg-8-2209-2011, 2011.

Owen, S. M., Boissard, C., and Hewitt, C. N.: Volatile organic compounds (VOCs) emitted from 40 Mediterranean plant species: VOC speciation and extrapolation to habitat scale, Atmos. Environ., 35, 5393-5409, doi:10.1016/S1352-2310(01)00302-8, 2001.

Paavolainen, L., Kitunen, V., and Smolander, A.: Inhibition of nitrification in forest soil by monoterpenes, Plant Soil, 205, 147-154, doi:10.1023/A:1004335419358, 1998.

Peñuelas, J. and Staudt, M.: BVOCs and global change, Trends Plant Sci., 15, 133-144, doi:10.1016/j.tplants.2009.12.005, 2010.

Peñuelas, J., Asensio, D., Tholl, D., Wenke, K., Rosenkranz, M., Piechulla, B., and Schnitzler, J. P.: Biogenic volatile emissions from the soil, Plant Cell Environ., 37, 1866-1891, doi:10.1111/pce.12340, 2014

Peräkylä, O., Vogt, M., Tikkanen, O. P., Laurila, T., Kajos, M. K., Rantala, P. A., Patokoski, J., Aalto, J., Yli-Juuti, T., Ehn, M., Sipilä, M., Paasonen, P., Rissanen, M., Nieminen, T., Taipale, R., Keronen, P., Lappalainen, H. K., Ruuskanen, T. M., Rinne, J. Kerminen, V.M., Kulmala, M., Bäck, J., and Petäjä, T.: Monoterpenes' oxidation capacity and rate over a boreal forest: temporal variation and connection to growth of newly formed particles, Boreal Environ. Res., 19, 293-293, 2014.

Pollard, M., Beisson, F., Li, Y., and Ohlrogge, J. B.: Building lipid barriers: biosynthesis of cutin and suberin, Trends Plant Sci., 13, 236-246, doi:10.1016/j.tplants.2008.03.003, 2008.

Pumpanen, J., Kolari, P., Ilvesniemi, H., Minkkinen, K., Vesala, T., Niinistö, S., Lohila, A., Larmola, T., Moreto, M., Pihlatie, M., Janssen, I., Yuester, J. C., Grunzweig, J. M., Reth, S., Subke, J.A., Savage, K., Kutsch, W., Østreng G., Ziegler, W., Anthoni, P., Lindroth, A., and Hari, P.: Comparison of different chamber techniques for measuring soil $\mathrm{CO}_{2}$ efflux, Agr. Forest Meteorol., 123, 159-176, doi:10.1016/j.agrformet.2003.12.001, 2004.

Ramirez, K. S., Lauber, C. L., and Fierer, N.: Microbial consumption and production of volatile organic compounds at the soil-litter interface, Biogeochemistry, 99, 97-107, doi:10.1007/S10533-009-9393-X, 2010.

R Core Team: R: A language and environment for statistical computing (version 3.2.4 R). R Foundation for Statistical Computing, Vienna, Austria, available at: http://www.R-project.org/ (last access: 28 February 2017), 2016.

Rinnan, R., Rinnan, ̊̊., Faubert, P., Tiiva, P., Holopainen, J. K., and Michelsen, A.: Few long-term effects of simulated climate change on volatile organic compound emissions and leaf chemistry of three subarctic dwarf shrubs, Environ. Exp. Bot., 72, 377-386, doi:10.1016/j.envexpbot.2010.11.006, 2011.

Rinnan, R., Gierth, D., Bilde, M., Rosenørn, T., and Michelsen, A.: Off-season biogenic volatile organic compound emissions from heath mesocosms: responses to vegetation cutting, Front. Microbiol., 4, 1-10, doi:10.3389/fmicb.2013.00224, 2013.

Rinne, J., Tuovinen, J. P., Laurila, T., Hakola, H., Aurela, M., and Hypén, H.: Measurements of hydrocarbon fluxes by a gradient method above a northern boreal forest, Agr. Forest Meteorol., 102, 25-37, doi:10.1016/S0168-1923(00)00088-5, 2000.

Rinne, J., Taipale, R., Markkanen, T., Ruuskanen, T. M., Hellén, H., Kajos, M. K., Vesala, T., and Kulmala, M.: Hydrocarbon fluxes above a Scots pine forest canopy: measurements and mod- 
eling, Atmos. Chem. Phys., 7, 3361-3372, doi:10.5194/acp-73361-2007, 2007.

Rohmer, M., Knani, M., Simonin, P., Sutter, B., and Sahm, H.: Isoprenoid biosynthesis in bacteria: a novel pathway for the early steps leading to isopentenyl diphosphate, Biochem. J., 295, 517524, 1993.

Rohmer, M., Seemann, M., Horbach, S., Bringer-Meyer, S., and Sahm, H.: Glyceraldehyde 3-phosphate and pyruvate as precursors of isoprenic units in an alternative non-mevalonate pathway for terpenoid biosynthesis, J. Am. Chem. Soc., 118, 2564-2566, 1996.

Schurgers, G., Arneth, A., Holzinger, R., and Goldstein, A. H.: Process-based modelling of biogenic monoterpene emissions combining production and release from storage, Atmos. Chem. Phys., 9, 3409-3423, doi:10.5194/acp-9-3409-2009, 2009.

Sindelarova, K., Granier, C., Bouarar, I., Guenther, A., Tilmes, S., Stavrakou, T., Müller, J.-F., Kuhn, U., Stefani, P., and Knorr, W.: Global data set of biogenic VOC emissions calculated by the MEGAN model over the last 30 years, Atmos. Chem. Phys., 14, 9317-9341, doi:10.5194/acp-14-9317-2014, 2014.

Smolander, A., Kanerva, S., Adamczyk, B., and Kitunen, V.: Nitrogen transformations in boreal forest soils - does composition of plant secondary compounds give any explanations?, Plant Soil, 350, 1-26, doi:10.1007/s11104-011-0895-7, 2012.

Stotzky, G., Schenck, S., and Papavizas, G. C.: Volatile organic compounds and microorganisms. CRC Cr. Rev. Microbiol., 4, 333-382, doi:10.3109/10408417609102303, 1976.
Van Roon, A., Parsons, J. R., Krap, L., and Govers, H. A.: Fate and transport of monoterpenes through soils. Part II: calculation of the effect of soil temperature, water saturation and organic carbon content, Chemosphere, 61, 129-138, doi:10.1016/j.chemosphere.2005.02.082, 2005.

Veres, P. R., Behrendt, T., Klapthor, A., Meixner, F. X., and Williams, J.: Volatile Organic Compound emissions from soil: using Proton-Transfer-Reaction Time-of-Flight Mass Spectrometry (PTR-TOF-MS) for the real time observation of microbial processes, Biogeosciences Discuss., 11, 12009-12038, doi:10.5194/bgd-11-12009-2014, 2014.

Walter, M. H., Fester, T., and Strack, D.: Arbuscular mycorrhizal fungi induce the non-mevalonate methylerythritol phosphate pathway of isoprenoid biosynthesis correlated with accumulation of the "yellow pigment" and other apocarotenoids, Plant J., 21, 571-578, doi:10.1046/j.1365-313x.2000.00708.x, 2000.

Wenke, K., Kai, M., and Piechulla, B.: Belowground volatiles facilitate interactions between plant roots and soil organisms, Planta, 231, 499-506, doi:10.1007/s00425-009-1076-2, 2010.

Wieder, W. R., Bonan, G. B., and Allison, S. D.: Global soil carbon projections are improved by modelling microbial processes, Nature Climate Change, 3, 909-912, doi:10.1038/NCLIMATE1951, 2013. 